\title{
32. BIOSTRATIGRAPHY OF LOWER CRETACEOUS BLAKE NOSE AND BLAKE-BAHAMA BASIN FORAMINIFERS DSDP LEG 44, WESTERN NORTH ATLANTIC OCEAN
}

\author{
Felix M. Gradstein, Geological Survey of Canada, Dartmouth, Nova Scotia
}

\begin{abstract}
Deep Sea Drilling Project Sites 390 and 392, Blake Nose, penetrated about 30 meters of nannofossil ooze and limestone rich in excellently preserved Lower Cretaceous planktonic (over 12 taxa) and benthic (over 50 taxa) foraminifers. Range charts are presented and four standard planktonic zones and one benthic zone are recognized which allow a detailed regional correlation.

Drilling at DSDP Site 391 (Blake-Bahama Basin) penetrated about 400 meters of dark and variegated claystone and light limestone and shale with sparse, poorly preserved foraminifers assigned to four assemblages or zones, comprising Valanginian, Barremian, Aptian-Albian, and Upper Cretaceous sediments.

One assemblage zone (Dorothia praehauteriviana) correlates Site 391 to Sites 101 and 105, DSDP Leg 11; another(Plectorecurvoides assemblage zone) may be diagnostic for the dark and variegated claystone facies both in the Atlantic and in the Pacific oceans.

The taxonomy and stratigraphic ranges of over 50 taxa are discussed and figured. Attention is focused on the intraspecific variation within the plexus Gavelinella-Lingulogavelinella on the basis of three previously described forms. Phylogenetic trends in the group of Gaudryina dividensSpiroplectinata are more complicated than previously established.
\end{abstract}

\section{INTRODUCTION}

During Leg 44 of the Deep Sea Drilling Project in the western North Atlantic Ocean, three sites, 389, 390, and 392 , were occupied on the edge of the Blake Plateau in water approximately 2650 meters deep. This region is known as the Blake Nose (Figure 1), a northeast-jutting spur of the Blake Plateau, about $500 \mathrm{~km}$ east of Florida, USA.

The main objective of drilling at the Blake Nose sites was to provide more detailed information on the presence of the Cretaceous reef complex that circles the Gulf of Mexico, extends through Cuba and the Bahamas, and rims the escarpment of the Blake Plateau (see Site 389 Report, this volume).

Drilling at Site 389 was an abortive attempt to spud in on the Blake Nose; only Quaternary microfossils were recovered. The successful and detailed coring at nearby Holes 390, 390A, and 392A yielded a Lower Cretaceous (Barremian-Albian), uppermost Cretaceous and Paleogene marine sequence over 170 meters thick as determined from assemblages rich in nannofossils, foraminifers, and also (Paleogene) radiolarians. The pelagic nature of the post-Barremian sediment, well above the calcium carbonate compensation depth (CCD) and the virtual absence of overburden have contributed to the excellent preservation of foraminifer tests.

We drilled another site, 391, south of the Blake Nose near the center of the Blake-Bahama Basin (Figure 1) in water 4963 meters deep. The site was located on the landward side of the quiet magnetic zone where we hoped to recover Middle and possibly Lower Jurassic strata overlying basaltic basement. The four holes of this site yielded a composite section from uppermost Jurassic through Lower Cretaceous (1412 T. D.-649 m), immediately overlain by thick Miocene and thinner

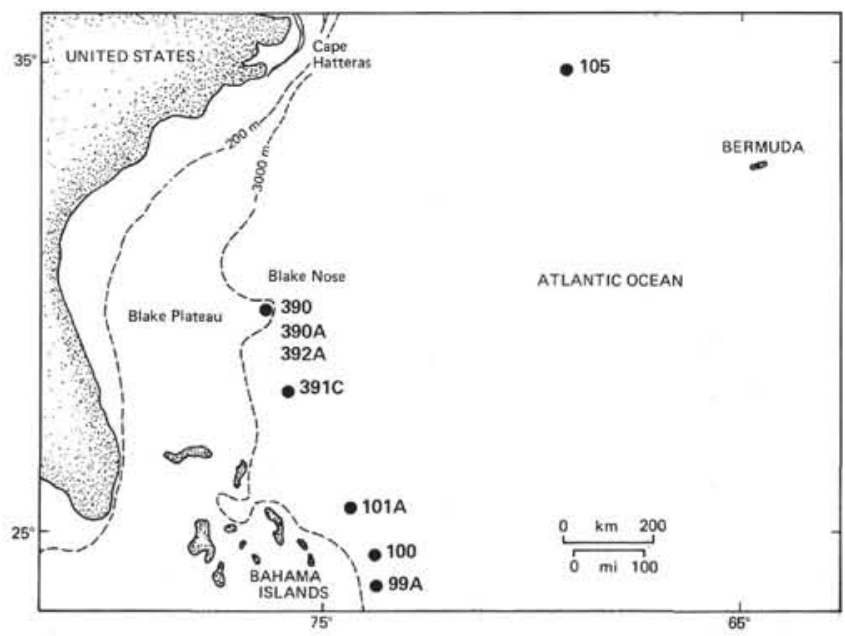

Figure 1. Location of Blake Nose Sites 390, 392 and BlakeBahama Site 391, Leg 44, Deep Sea Drilling Project. Sites 99, 100, 101, and 105, Leg 11, where Lower Cretaceous strata were cored are also shown. 
Quaternary beds. The presence of Upper Cretaceous strata could not be determined conclusively.

Upper Jurassic and Lower Cretaceous foraminifers (in Hole 391C) are few and poorly preserved: many core samples are barren. We attribute this in part to synsedimentary dissolution of tests at depth. The foraminiferal biostratigraphy is accordingly meager, especially if compared to the record in the Blake Nose sites.

The multiple biostratigraphic and paleoecologic interpretations at each site are presented in the individual site reports (Part I, this volume).

This chapter is an account of the planktonic and benthic foraminifer biostratigraphy from the Lower Cretaceous beds, mainly at Sites 390 and 392. Some time was spent in examination of the variation in many taxa, details of which are in the Appendix on taxonomy. Most taxa are illustrated in Plates 1-11. Some of the determinations are provisional, pending more complete documentation of the variation in morphology and comparison to type material.

The Lower Cretaceous foraminifer stratigraphy of Site 391 shows little resemblance to the one of DSDP Sites 99, 100, 101, and 105, as studied by Luterbacher (1972). We make a brief comparison below in the paragraph on Regional Correlation.

\section{PREVIOUS LITERATURE}

Piston coring and dredgings along the Blake Escarpment, which separates the 1000 -meter level of the Blake Plateau from the 5000-meter depth of the Blake-Bahama Basin, has revealed the presence of Neocomian to Aptian algal limestone and (?AlbianCenomanian pelagic sediments (Sheridan and Osburn, 1974; Loeblich and Tappan, 1961; see also Saito et al., 1974). Other than Orbitolina and miliolids, no foraminifers were found in the limestone. Loeblich and Tappan (1961) identified the pelagic foraminifers from Core A167-25. According to these authors, "The benthonic foraminifera in the core include some species typical of outcropping strata ranging from the Trinity (lower Albian) through Fredericksburg and Washita (Albian-Cenomanian) in the Gulf Coast." The planktonic species include Hedbergella washitensis (Carsey), H. planispira (Tappan), H. trocoidea (Gandolfi), Globigerinelloides bentonensis (Morrow), $G$. eaglefordensis (Moreman), Praeglobotruncana delrioensis (Plummer), and Rotalipora greenhornensis (Morrow), which lead the authors to postulate a midCenomanian age for the cored sediment.

During DSDP Leg 11 (Miami-Hoboken) Lower Cretaceous sediments were cored in Holes 99A, 100, and $101 \mathrm{~A}$, immediately northeast of the Bahama's in the Blake-Bahama Abyssal Plain and in Hole 105, near the northern end of the Hatteras Abyssal Plain, approximately $600 \mathrm{~km}$ to the east of Cape Hatteras (see Figure 1).

The sediments cored are Tithonian-Neocomian light gray limestone and nannofossil ooze with thin interbeds of carbonaceous clay and chert and Hauterivian-lower Cenomanian black and green carbonaceous clay, Foraminifers, described by Luterbacher (1972), almost invariably occur rarely and in patches. Species include:

A) Tithonian-Valanginian: Vaginulina sp. aff., $V$. biochei (Terquem), Lenticulina nodosa (Reuss) $L$. subalata (Reuss), Frondicularia simplicissima Ten Dam, and age-diagnostic calpionellids belonging in the genera Calpionella, Calpionellopsis, Remaniella, and Tintinnopsella.

B) ?Valanginian: Dorothia praehauteriviana Dieni and Massari.

C) Upper Valanginian-Hauterivian: Lenticulina ouachensis ouachensis (Sigal), L. ouachensis multicella Bartenstein, Bettenstaedt, and Bolli and an agediagnostic aptychi faunule.

D) Hauterivian-Albian: Hedbergella infracretacea (Glaessner), $H$. hauterivica (Subbotina), $H$. globigerinelloides (Subbotina), G. ultramicrus (Subbotina), Hoglundina? sp., and Gavelinella sp. aff. G. barremiana Bettenstaedt.

E) Upper Albian-lower Cenomanian: Rotalipora apenninica apenninica (Renz), $R$. apenninica primitiva Borsetti, Praeglobotruncana delrioensis (Plummer), Planomalina buxtorfi (Gandolfi), Hedbergella trocoidea (Gandolfi), and H. amabilis Loeblich and Tappan.

\section{BIOSTRATIGRAPHY}

The Lower Cretaceous planktonic biostratigraphy of Sites 390, 391, and 392 follows van Hinte's (1976) zonal scheme in consulation with taxonomic and biostratigraphic data mainly by Bolli (1959), Moullade (1966), Sigal (1965; 1966), Hermes (1969), Kuhry (1971), and Longoria (1974). I recognized four formal zones (Figure 2) in sediments from Sites 390 and 392:

Ticinella breggiensis Zone (LC17)—upper Albian

Ticinella primula Zone (LC15-16) -middle Albian

Globigerinelloides algerianus Zone (LC11)-upper Aptian

Globigerinelloides blowi Zone (LC9)-lower Aptian The informal Barremian benthic zone of Gavelinella barremiana-Lenticulina (Marginulopsis) sigali, erected for Sites 390, 391, and 392 is correlated to the Barremian-lower Aptian planktonic zone of Hedbergella sigali (LC8).

For the benthic foraminifers, I used the ranges of species as given by a number of authors quoted in the text, including Bartenstein et al. (1957, 1966, 1973); Simon and Bartenstein (1962); Sigal (1965); Moullade (1966); Michael (1966, 1967); Ohm (1967); Dailey (1970); Luterbacher (1972); Scheibnerova (1974); van Hinte (1976); and Bartenstein (1976a, b). Two informal benthic zones erected in the sites include Gaudryina ex. gr. dividens Zone (upper Aptian-middle Albian) and Gravelinella barremiana-Lenticulina (M.) sigali Zone (Barremian) (Figures 2, 3, 4). I also recognized three intervals in sediments from Site 391 with more or less age-diagnostic assemblages (Figure 2): Plectorecurvoides assemblage (?Albian-Upper Cretaceous), Hedbergella trocoidea assemblage (upper Aptian-lower Albian), and Dorothia praehauteriviana assemblage (Valanginian). Figure 2 shows the correlation of the Lower Cretaceous beds in Sites 390, 391, and 392 on the basis of foraminifer stratigraphy. It also gives the predominant 


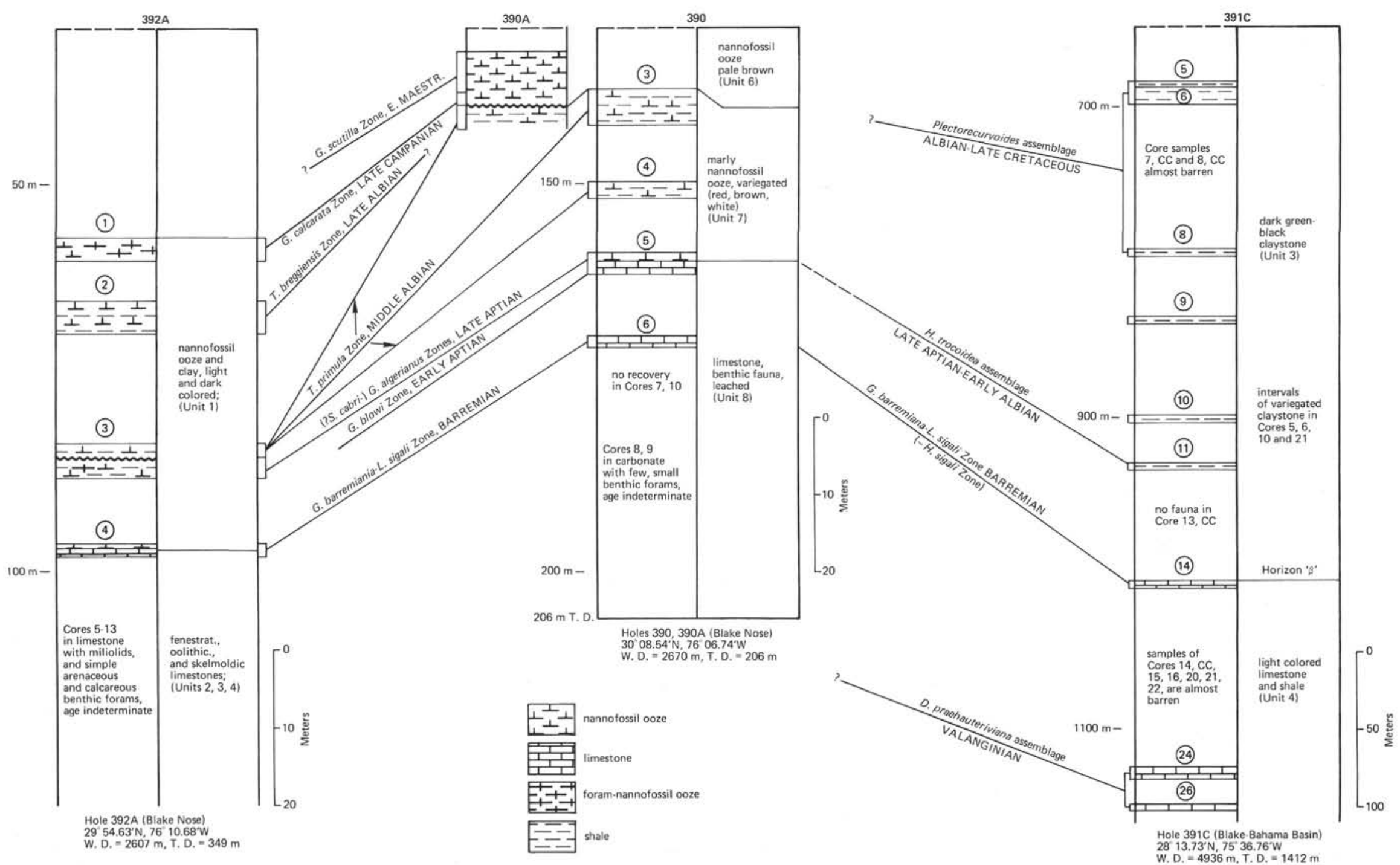

Figure 2. Lower Cretaceous foraminifer biostratigraphy and lithology of Blake Nose Sites (390 and 392), and Blake-Bahama Basin Site (391), Leg 44, Deep Sea Drilling Project. Hole 392A, Core 1, and the upper part of Hole 390A, Core 14, consist of Campanian-Maestrichtian pelagic sediments. 


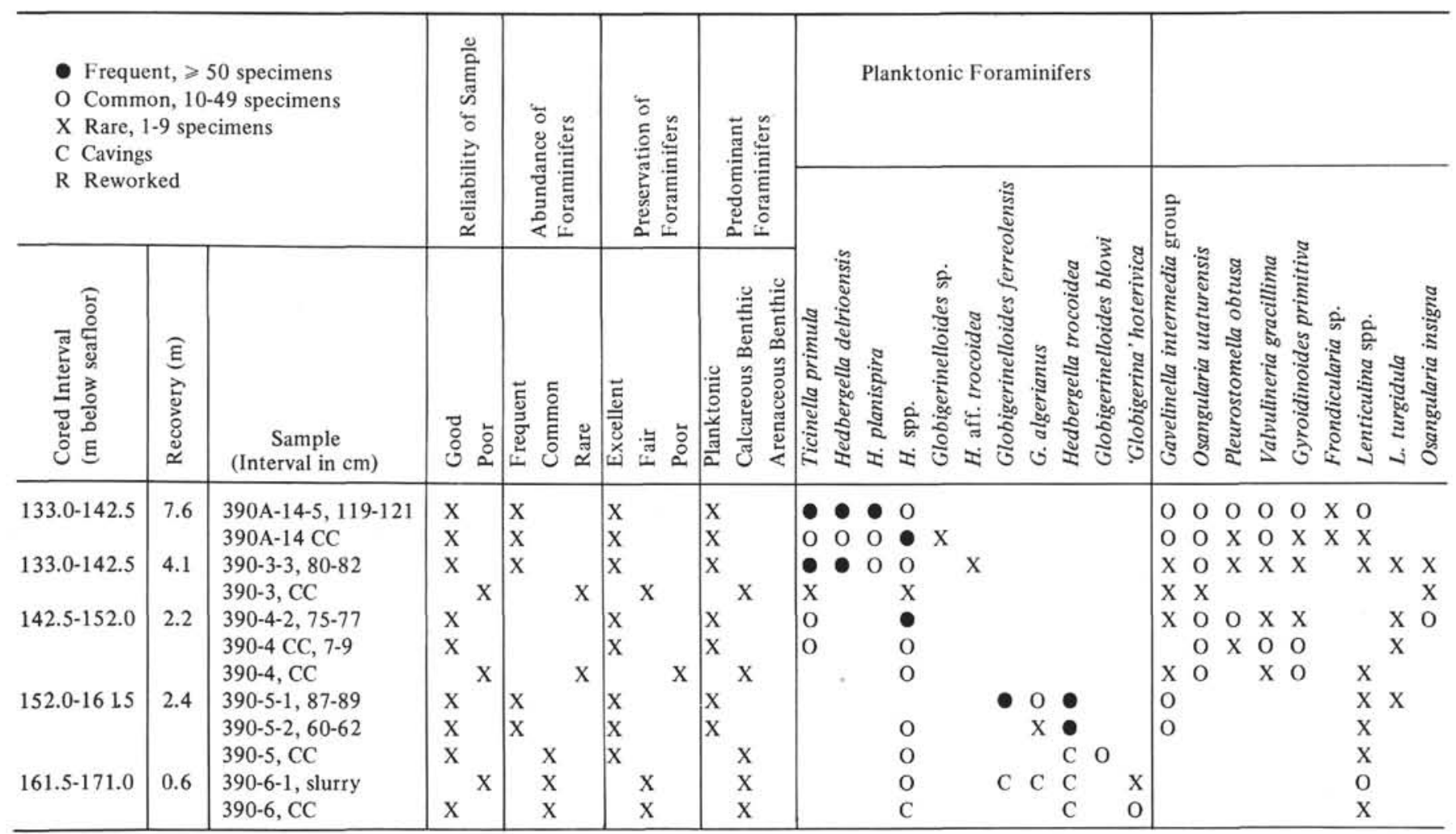

Figure 3. Distribution and biostratigraphy of Lower Cretaceous foraminifers at Site 390 (including Hole 390A), Blake Nose.

Lower Cretaceous lithology as taken from the individual Site Reports (Part II, this volume). Distribution charts of the Lower Cretaceous faunal succession at Sites 390 and 392 are given in Figures 3 and 4. No distribution chart was prepared from the poor and patchy record from Site 391, but the taxa are listed according to depth in the Appendix.

The zones and assemblages are discussed below in ascending stratigraphic order.

Dorothia praehauteriviana Assemblage (Valanginian; Hole 391C, Core 26, Section 3, 60-62 cm and Core 24, Section 3, 14-16 cm; light colored limestone and shale)

The co-occurrence in Hole $391 \mathrm{C}$ of Dorothia praehauteriviana Dieni and Massari (Plate 1, Figures $13,14)$ with isolated specimens of Conorboides hofkeri (Bartenstein and Brand) (Plate 1, Figure 15) and Lenticulina ex. gr. nodosa (Reuss) (Plate 1, Figure 16), indicates a Valanginian age (see Bartenstein, 1976b). The only other foraminifers are undiagnostic species of Lenticulina, Haplophragmoides, Eoguttulina, Vaginulopsis, Glomospira, and Glomospirella; pyritized radiolarians are common.

Dorothia praehauteriviana Dieni and Massari includes many, well preserved, stout specimens. Its presence correlates Cores 24 and 26 at Site 391 to DSDP Sites 101, Core 10A and Site 105, Cores 19-21 which were tentatively dated Valanginian by Luterbacher (1972; cf. Dieni and Massari 1966).

On the basis of palynomorphs and nannofossils, the interval at Site Site 391 is dated, respectively, upper Valanginian-lower Hauterivian and upper Berriasianlower Valanginian (Schmidt and Habib, this volume).
Gavelinella barremiana-Lenticulina $(M$.) sigali Zone (Barremian; basal nannofossil ooze and uppermost limestone in Hole 392 A, Core 4; Hole 390, Core 6; top of light colored limestone unit in Hole 391C, Core 14, Section 3, 66-68 cm)

The assemblage in Hole 391C of this informal zone consists of rare, etched specimens of Hedbergella sigali Moullade (Plate 1, Figure 11); Gavelinella barremiana Bettenstaedt (Plate 1, Figures 9, 10); and Lenticulina (Planularia) crepidularis (Roemer) (Plate 1, Figure 12). The zone correlates with the lower part of the Barremian-lower Aptian Hedbergella sigali Zone (LC8) (van Hinte, 1976).

At Sites 390 and 392, the informal Gavelinella barremiana-Lenticulina $(M$.$) sigali Zone contains a$ variety of species. Restricted to the interval are Lenticulina (Marginulopsis) sigali Bartenstein, Bettenstaedt, and Bolli (Plate 4, Figures 5-7); $L$. crepidularis (Roemer) (Plate 4, Figure 9); L. ex gr. nodosa (Reuss) (Plate 4, Figure 10); L. meridiana Bartenstein, Bettenstaedt, and Kovatcheva (Plate 4, Figure 2); Epistomina ornata (Roemer) (Plate 4, Figure $11) ;$ E. caracolla (Roemer); E. aff. ornata (Roemer); Conorotalites intercedens (Bettenstaedt) (only present at Site 390).

In Hole 390, Core 6, there also are a dozen or more specimens of "Globigerina" hoterivica Subbotina (Plate 9, Figures 9-15) (syn. G. kugleri Bolli from the Cuche and Toco formations, Barremian-Aptian of Trinidad). Van Hinte (1976), (?following Subbotina's [1953] first description), restricts the species to upper Hauterivian strata. Michael (1967) seems to give the maximum range, i.e., upper Hauterivian to lower Aptian. 


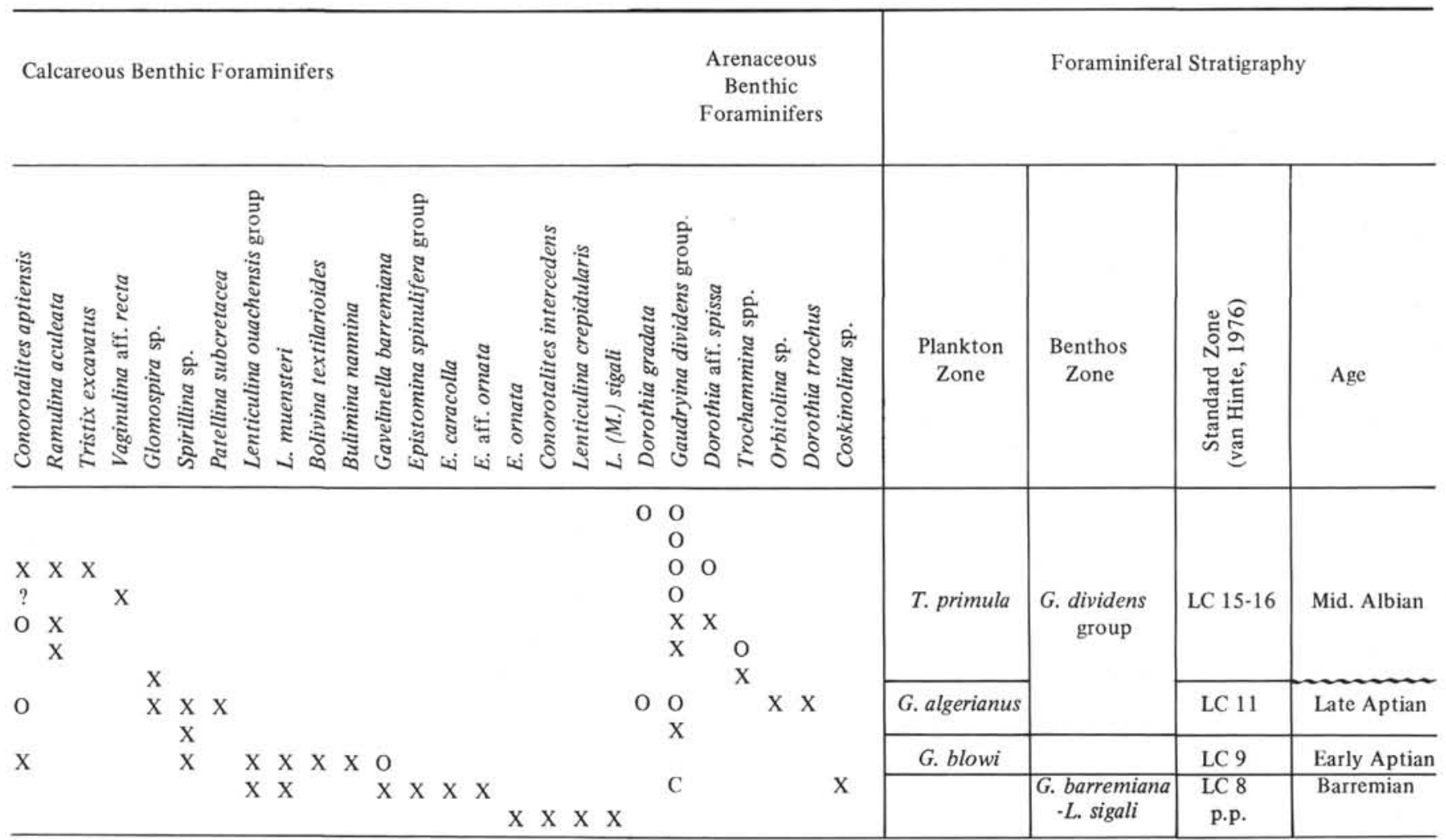

Figure 3. Continued.

The following species present also occur in overlying Aptian-Albian strata at Sites 390 and 392: Lenticulina ex. gr. ouachensis Sigal (Plate 4, Figures 4, 8); $L$. muensteri (Roemer); Gavelinella barremiana Bettenstaedt (Plate 6, Figures 14-17); Epistomina ex. gr. spinulifera (Reuss) (Plate 8, Figures 1, 2); Conorotalites aptiensis (Bettenstaedt) (Plate 8, Figures 13, 17; only present in this zone at Site 392).

Conorotalites intercedens-aptiensis is known from middle-upper Barremian strata (e.g., Simon and Bartenstein, 1962; Sigal, 1965). Ranges of other species are: Epistomina caracolla and E. ornata, Valanginianmiddle Barremian (Ohm, 1967; Bartenstein, 1976b); Lenticulina $(M$.$) sigali, Hauterivian-Barremian (Sigal,$ 1965, sub Marginulopsis cf. djaffaensis; Bartenstein et al., 1957); L. crepidularis, long ranging but locally more common in upper Valanginian-lower Barremian beds (Simon and Bartenstein, 1962); Epistomina ex. gr. spinulifera, middle Barremian-Albian (Sigal, 1965; Ohm, 1967); Lenticulina meridiana, Hauterivian-lower Albian with peak in Hauterivian-Barremian (Bartenstein and Bolli, 1973; Bartenstein, 1976b); $L$. ouachensis, Hauterivian-Aptian (Bartenstein, 1976b); Gavelinella barremiana, middle-upper Barremian, ?Aptian (see discussion under $G$. blowi Zone).

These ranges suggest that the assemblage which defines the informal zone of Gavelinella barremianaLenticulina (M.) sigali is lower-late Barremian in age.

Habib (this volume) dates Core 14 (as high as Section 2) in Hole 391C as upper Hauterivian or Barremian through lower Aptian. On the basis of nannofossil determinations, Schmidt (this volume) assigns the interval of Cores 14-22 to the upper Valanginian through ?upper Barremian. In Hole 390, Core 6, and Hole 392A, Core 4, nannofossils comprise the Barremian $M$. hochschulzi Zone-in close agreement with foraminifer age assignment.

Specimens in this zone in Holes 390 and 392A of Gaudryina dividens Grabert, Hedbergella trocoidea (Gandolfi), Globigerinelloides alterianus Cushman and Ten Dam, and G. ferrolensis (Moullade) are interpreted as cavings. The same may be true for indeterminate Hedbergella. The tests of these taxa, mostly large specimens, are also less carbonate coated than most found at this level; the preservation is more comparable to that of the same taxa in the overlying upper Aptian strata

\section{Globigerinelloides blowi Zone (LC9; lower Aptian; top of limestone in Hole 390, Core 5, CC)}

The presence in Sample 5, CC in Hole 390 of the lower Aptian partial range zone of Globigerinelloides blowi (LC9; van Hinte, 1976) is established on the basis of the presence of Globigerinelloides blowi Bolli, together with Conorotalites aptiensis (Bettenstaedt), Lenticulina ex. gr. ouachensis (Sigal), and Gavelinella barremiana Bettenstaedt (?-G. intermedia [Berthelin]). The latter two species do not range stratigraphically higher on the Blake Nose. Also present are Lenticulina muensteri (Roemer), Praebulimina nannina (Tappan) (Plate 9, Figures 16, 17), Bolivina textilarioides (Reuss), Spirillina sp., and small Hedbergella spp.

The zone has only been recognized in Hole 390, but it might also be present in Hole $392 \mathrm{~A}$ in the interval between Cores 3 and 4 (see Figure 2). 


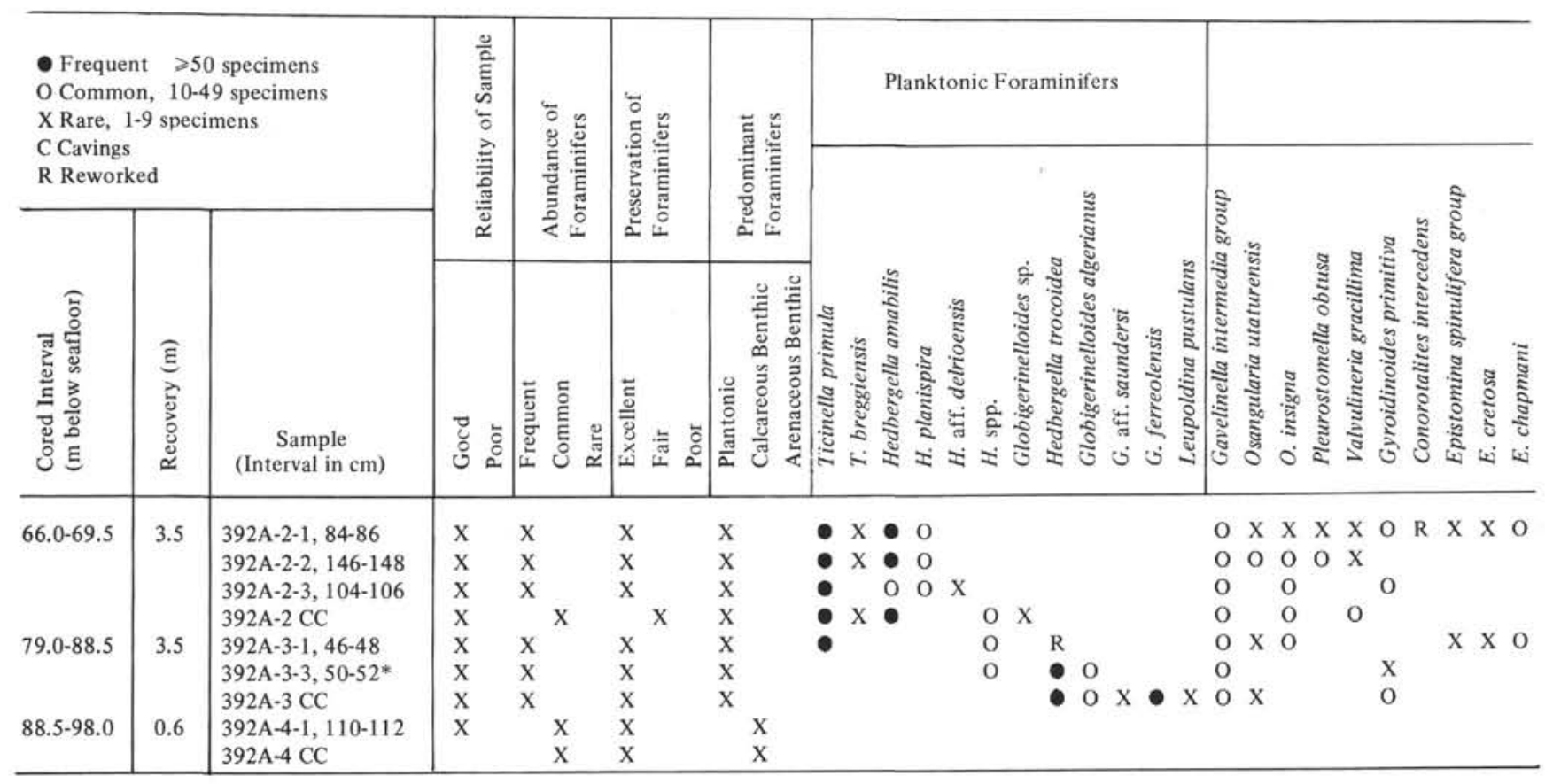

* 392A-3-2, 121-123 cm belongs in the same zone.

Figure 4. Distribution and biostratigraphy of Lower Cretaceous foraminifers in Hole 392A, Blake Nose.

Paleontologists are not certain whether Globigerinelloides blowi (Bolli) ranges throughout the Lower Aptian or only appears in its upper part as suggested by Moullade (1966) (see also Bolli, 1959; Longoria, 1974; van Hinte, 1976).

There is no agreement in the literature on the stratigraphic range of Gavelinella barremiana Bettenstaedt. According to Michael (1966) the species sensu strictu is indicative of middle-upper Barremian strata (cf. van Hinte, 1976), but as a variant of $G$. intermedia (Berthelin) morphologically similar specimens persist in the Aptian. Many authors, including Moullade (1966) and Bartenstein (1976b) show a middle Barremianlower Aptian range. In Sample 390-5, CC, 1 of 24 specimens examined is morphologically intermediate between $G$. barremiana s.s. and $G$. intermedia s.s. The other specimens show the typical $G$. barremiana morphology and are similar to the specimens in the underlying zone.

Possibly the core-catcher sample incorporates some Barremian sediments and on the basis of nannofossil stratigraphy the sediment of 390-5, CC was assigned to the upper Barremian (Schmidt, this volume). However, except for $G$. barremiana, Barremian foraminifer species from the underlying zone are absent (Figures 3, 4).

The presence of some specimens of Hedbergella trocoidea (Gandolfi) in this sample with identical preservation to that of the proliferous and in situ specimens in the overlying strata is explained from cavings.
Globigerinelloides algerianus Zone (LC11; upper Aptian; marly nannofossil ooze and clay, variegated; Hole 390, Core 5, Sections 1, 2; Hole 392A, Core 3, Sections 2 and 3)

Rich assemblage with up to approximately 90 per cent of well-preserved planktonic taxa. The presence of Globigerinelloides algerianus Cushman and Ten Dam (Plate 10, Figures 9-13) is the basis for the planktonic zone designation.

Other planktonic taxa restricted to this interval are: G. ferreolensis (Moullade) (Plate 10, Figures 14-17; Plate 9, Figures 1-4); G. aff. saundersi (Bolli) (Plate 10, Figure 4); Leupoldina pustulans (Bolli) (Plate 10, Figure 3); and Hedbergella trocoidea (Gandolfi) (Plate 10, Figures 5,6). The latter species is especially common. Longoria (1974) restricts Leupoldina pustulans (Bolli) and Globigerinelloides saundersi (Bolli) more or less to the upper Aptian Leupoldina cabri Zone, which occurs below the Globigerinelloides algerianus total range zone. However, there appears to be no agreement in the literature on the exact ranges of these species. The presence of specimens resembling these taxa in the lower one of two samples in Hole 392A, Core 3 with $G$. algerianus might be an indication of a condensed section representing the upper Aptian Schackoina cabri Zone (LC10)-Globigerinelloides algerianus Zone (LC11) (sensu van Hinte, 1976; Longoria, 1974). However, in the absence of Schackoina cabri Sigal, this interpretation is more or less speculative.

Among the benthics, Lenticulina vocontiana 


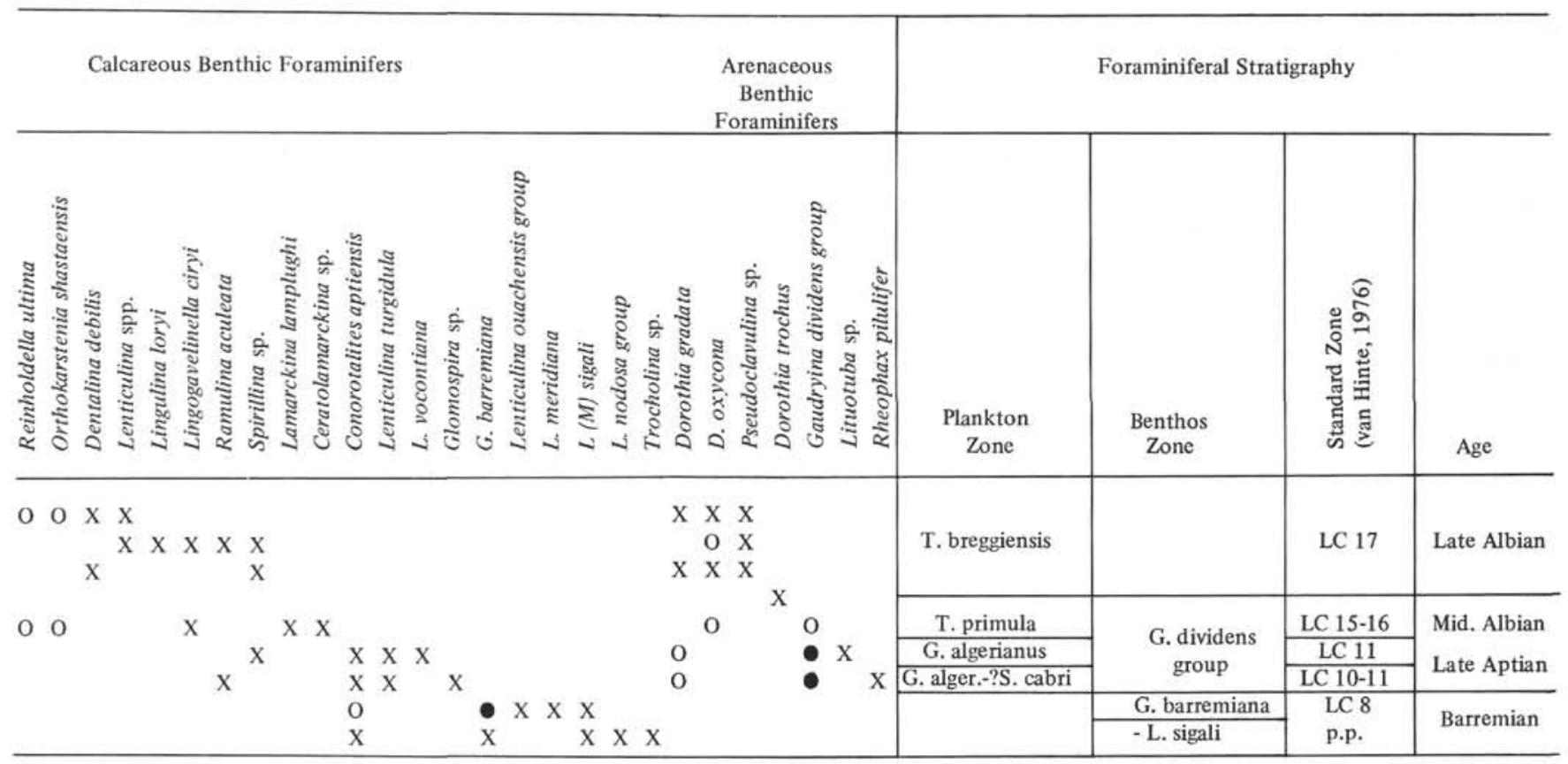

Figure 4. Continued.

Moullade (Plate 4, Figure 1) has only been found in this zone. The species is known from the upper Aptian of France, and the upper Aptian-lower Albian of Trinidad (Moullade, 1966; Bartenstein and Bolli, 1973).

Benthic species which have their stratigraphically lowest occurrence in the interval in the Blake Nose Sites are: Gaudryina ex. gr. dividens Grabert (Plate 2); Gavelinella ex. gr. intermedia (Berthelin) (Plate 6, Figures 5-13); Osangularia utaturensis (Sastri and Sastry) (Plate 7, Figures 5-12); Lenticulina turgidula (Reuss) (Plate 4, Figure 3); Gyroidinoides primitiva Hofker (Plate 8, Figures 9, 10); Dorothia gradata Berthelin (Plate 3, Figures 14-17). Gaudryina ex. gr. dividens and Gavelinella ex. gr. intermedia are most commion. Both taxa and their related forms are discussed in some detail in the Appendix to this chapter.

Osangularia utaturensis (Sastri and Sastry), particularly common in Blake Nose Albian strata, is a cosmopolitan species known from (upper) Aptian through Albian beds (syn. O. sp. aff. brotzeni Gandolfi and $O$. californica Dailey; see Appendix).

The Globigerinelloides algerianus Zone at Sites 390 and 392 corresponds to the upper Aptian-lower Albian $P$. angustus nannofossil zone (Schmidt, this volume).

Gaudryina ex gr. dividens Zone (upper Aptian-middle Albian; Hole 392A, Core 3; Hole 390, Core 5, Section 2, through Core 3, Section 3 and Hole 390A, Core 14, Section 5).

Because of its conspicuous morphology, abundance, and restricted range in Blake Nose samples, I have taken the presence of Gaudryina ex. gr. dividens Grabert (Plate 2) to comprise an informal zone. It correlates Hole 392A, Core 3 to Hole 390, Section 5-2 through
Section 3-3 and to Hole 390A, Section 14-5. Following Grabert (1959; see also Simon and Bartenstein, 1962, and Bartenstein, 1976b) the taxon (and the morphologically closely associated Spiroplectinata lata Grabert; see description of the GaudrylinaSpiroplectinata plexus in Appendix) ranges from upper Aptian to middle Albian in agreement with the Blake Nose planktonic biostratigraphy (see distribution charts of Figures 3,4). On Sigal's (1965) range chart of Lower Cretaceous foraminifers Gaudryina dividens ranges from upper Barremian through (lower) Albian.

Hedbergella trocoidea Assemblage (upper Aptian-lower Albian; dark green-black claystone in Hole 319C, Core 11, Section 3, $45-47 \mathrm{~cm}$ )

In Hole $391 \mathrm{C}$ the only foraminifer evidence of Aptian-Albian beds is from tiny specimens of Hedbergella trocoidea (Gandolfi), Globigerinelloides aff. ferreolensis (Moullade), and Gavelinella aff. intermedia (Berthelin) in Core 11. The species date the sample as upper Aptian-lower Albian. This agrees with age determinations for this depth by Habib (palynomorphs, this volume) and Schmidt (nannofossils, this volume).

Ticinella primula Zone (LC15-16; middle Albian; marly nannofossil ooze and clay, variegated; Hole 390, Cores 4, CC and 4, Section 2, 75-77 cm; Cores 3, CC and 3, Section 3, 80-82 cm; Hole 390A, Cores 14, CC and 14, Section 5, 119-121 cm; Hole 392A, Core 3, Section 1, 46$48 \mathrm{~cm}$ )

Interval with prolific pelagic foraminifers, characterized by Ticinella primula Luterbacher (Plate 11, Figures 3-10) stratigraphically below the first occurrence of $T$. breggiensis (Gandolfi). The species dominates the assemblage. Except for isolated, 
relatively poorly preserved (?reworked) specimens in Hole 390-3-3, 80-82 cm of Hedbergella aff. trocoidea (Gandolfi) (Plate 10, Figures 7, 8) and of some reworked $H$. trocoidea in Sample 392A-3-1, 46-48 cm, planktonic species from the underlying Globigerinelloides algerianus Zone are absent. The interpretation "reworked" in Section 392A-3-1 stems from the opaque, sugary preservation of the (few) specimens which are like that in the $G$. algerianus Zone and unlike the smooth, translucent tests in this zone.

The presence of Ticinella primula Luterbacher, the absence of Globigerinelloides ferreolensis (Moullade) and of specimens clearly belonging to Hedbergella trocoidea (Gandolfi) and the absence of Ticinella breggiensis (Gandolfi) indicates Moullade's (1966) and van Hinte's (1976) middle Albian partial range zone with Ticinella primula (LC15-16).

Other taxa which have their lower stratigraphic occurrence in this Blake Nose interval are Hedbergella delrioensis (Carsey) (Plate 10, Figures 1, 2); $H$. planispira (Tappan) (Plate 11, Figures 14-16); Osangularia insigna Dailey (Plate 7, Figures 1-4); Pleurostomella obtusa Berthelin (Plate 3, Figures 6-8, 11); Valvulineria gracillima Ten Dam (Plate 8, Figures 11, 12); Lingulogavelinella ciryi Malapris-Bizouard (Plate 5, Figures 13-17); Epistomina cretosa Ten Dam (Plate 8, Figures 3, 4); E. chapmani Ten Dam (Plate 8, Figure 5); Reinholdella ultima Dailey (Plate 8, Figures 7, 8); Orthokarstenia shastaensis Dailey (Plate 3, Figures 1-4); and Dorothia oxycona Reuss. Dorothia aff. spissa (Berthelin), Lamarckina lamplughi (Sherlock), Vaginulina aff. recta Karrer, and Tristix excavatus (Reuss) (Plate 3, Figure 10) are confined to this interval.

Many of the benthic species are only represented by a few specimens (see Figures 2, 3), and their scattered presence in Albian beds of the Blake Nose could be a function of sampling. Most of the above species are known from Aptian/Albian strata (see Appendix) except possibly Osangularia insigna Dailey from the (upper) Albian-Cenomanian of California (Dailey, 1970).

Gaudryina ex. gr. dividens Grabert and Conorotalites aptiensis (Bettenstaedt) do not range stratigraphically above this zone on the Blake Nose, in agreement with a lower-middle Albian upper limit elsewhere (see Grabert, 1959; Simon and Bartenstein, 1962; Sigal, 1965; Bartenstein, 1976b).

Nannofossils in the Ticinella primula Zone on the Blake Nose are, respectively, assigned an upper Aptianlower Albian and lower-middle Albian age (special chapters by Schmidt and Roth, this volume).

Ticinella breggiensis Zone (LC17; upper Albian nannofossil ooze and clay, variegated; Hole $392 \mathrm{~A}$, Core 2)

In Hole 390A in the lower part of Core 14, the middle Albian Ticinella primula Zone is immediately overlain by the upper Campanian Globotruncana calcarata Zone (Site 390 Report; Part I of this volume). At Site 392 the Albian section below the disconformity with the upper Campanian strata appears more complete.
Core 2 of Hole 392A has a rich, largely pelagic assemblage with Ticinella breggiensis (Gandolfi) (Plate 11, Figure 1), and Hedbergella amabilis Loeblich and Tappan (Plate 11, Figures 11-13), which are restricted to this interval. $H$. planispira Tappan, $H$. aff. delrioensis (Carsey), and Ticinella primula Luterbacher also occur. Specimens transitional between $T$. primula and T.breggiensis are common (Plate 11, Figure 2).

Most workers agree that $T$. breggiensis occurs in the upper Albian (see Longoria, 1974, p. 96 for a summary of the literature). A few references, including Sigal (1966), mention a middle Albian appearance. In van Hinte's (1976) zonal scheme (sensu Moullade, 1966) this species characterizes the $T$. breggiensis total range zone of lower upper Albian. It evolved from $T$. primula as is also suggested in our material.

Among the benthic species specimens of Dentalina debilis (Berthelin) (Plate 3, Figure 9) and Lingulina loryi (Berthelin) were not found below this zone. However, these species appear to be relatively long ranging (Hauterivian-Albian/Cenomanian, see Maync, 1973; Dailey, 1973). The other benthic species present also occur in the underlying zone of Ticinella primula Luterbacher. Epistomina ex. gr. spinulifera (Reuss) (Plate 8, Figures 1,2) occurs with some relatively large specimens which are much better preserved than the few individuals present in the zone of $G$. barremiana- $L$. (M.) sigali.

Nannofossils in Hole 392A, Core 2 have been assigned to the lower-middle Albian (Schmidt, this volume).

Plectorecurvoides Assemblage (?Albian-Upper Cretaceous; dark green-black claystone; rare variegated intervals, Hole 391C, Cores 5 to 8, possibly as deep as Core 10)

In Hole 391C, Samples 5, CC, 6, CC, and 8, CC between 677.5 meters and \pm 800 meters below sea bottom there is an exclusively siliceous arenaceous foraminifer assemblage. Many other samples in this dark claystone interval lack foraminifers.

Taxa determined include Plectorecurvoides sp. (common) (Plate 1, Figures 1, 2); Bolivinopsis (Plate 1, Figure 5); Uvigerinammina sp. (Plate 1, Figure 7); Trochammina globigeriniformis (Parker and Jones) (Plate 1, Figure 4); Trochammina sp. (Plate 1, Figure 3); Recurvoides sp., Hormosina sp., Bathysiphon sp., Glomospira sp. (Plate 1, Figure 6); Glomospirella sp. (Plate 1, Figure 8); Rheophax sp.; ?Textularia sp.; Ammobaculites spp.; and Spirillina sp.; there are serpulids in Sample 6, CC. All specimens are relatively small.

The best and most diversified arenaceous fauna is in variegated claystone beds, as in Sample 5, CC. The arenaceous fauna may well be characteristic of the dark, variegated claystone. Luterbacher (1972) reported a fauna of simple-structured arenaceous foraminifers from the Lower Cretaceous black clay interval at Site 101, Blake-Bahama Basin, with ageundiagnostic genera Rhizammina, Bathysiphon, Reophax, Haplophragmoides, ?Ammovertella, and 
"Spirillina." Krasheninnikov (1973) found a fauna, quite similar to the $391 \mathrm{C}$ fauna in variegated clays in the Pacific Ocean; he assigned it to the Upper Cretaceous.

In the case of Plectorecurvoides assemblage in Hole $391 \mathrm{C}$, I tentatively assigned it to the Albian-Upper Cretaceous on the basis of the ranges of Uvigerinammina, Bolivinopsis, Plectorecurvoides, and Glomospirella (see Loeblich and Tappan, 1964).

In Samples 391C, 9-2, 48-50 cm, and 10-2, 73-74 cm, isolated, poorly preserved, and small calcareous tests of Hedbergella and Patellina were found which would indicate a Cretaceous age. Tiny, well preserved tests of Globigerina and radiolarians found in Sample 5, CC and some deeper samples are probably contaminants, either from cavings or introduced during handling of the samples and/or residues.

Nannofossils in Cores 9 and 10 of Hole 391C are upper Aptian-lower Albian (Schmidt, this volume), palynomorphs in Cores 6-8 are dated as upper Albian, and in Cores 8-14 as upper Aptian-lower Albian (Habib, this volume).

\section{BLAKE NOSE BARREMIAN-ALBIAN BIOSTRATIGRAPHIC RECORD}

A comparison of the Barremian-Albian zones recognized in the Blake Nose Sites 390 and 392 with the standard zonation as compiled from many sources by van Hinte (1976) shows one conspicuous gap (Table 1). The gap is formed by the absence of Zones LC12-LC14, uppermost Aptian-lower Albian. The most notable species missing are "Globigerinelloides" gyroidinaeformis Moullade and Ticinella bejaouaensis Sigal.

At Hole 390 this gap might be caused by the lack of samples between Cores 5 (LC11) and 4 (LC15-16). However, in Hole 392A, LC11 almost immediately underlies LC15-16 within Core 3 (Figure 2).

Zone LC11 in Hole 392A has been recognized as high as Sample 3-2, 121-123 cm, whereas a sample of Core 3$1,46-48 \mathrm{~cm}$ belongs in Zone LC15-16. The contact (or a highly condensed section representing uppermost Aptian-lower Albian strata) appears to be missing in the core.

Another gap in the Aptian-Albian Blake Nose record, as discussed earlier, is the absence of the

TABLE 1

Barremian-Albian Zones Recognized in the Blake Nose Sites Compared with Standard Zonation

\begin{tabular}{|c|c|}
\hline Standard Zones & $\begin{array}{r}\text { Blake Nose } \\
(\mathrm{x}=\text { present })\end{array}$ \\
\hline T. breggiensis LC17 & $\mathrm{x}$ \\
\hline T. praeticinensis LC16 & \\
\hline $\begin{array}{l}\text { T. bejaouaensis-G. gyroidinaeformis- } \\
\text { T. primula LC15 }\end{array}$ & $x$ \\
\hline T. bejaouaensis- $G$. gyroidinaeformis LC14 & \\
\hline G. ferreolensis-T. bejaouaensis LC13 & \\
\hline H. trocoidea-G. ferreolensis $\mathrm{LC} 12$ & \\
\hline Gl. algerianus LC11 & $\mathrm{x}$ \\
\hline S. cabri LC10 & $? \mathrm{x}$ \\
\hline G. blowi LC9 & $\mathrm{x}$ \\
\hline H. sigali LC8 & $\mathrm{x}$ (equivalent p.p.) \\
\hline
\end{tabular}

Ticinella breggiensis Zone (LC17) in Hole 390A. At this site the upper Campanian Globotruncana calcarata Zone immediately overlies the middle Albian Ticinella primula Zone in Core 14 (Figure 2).

The absence of the lower Aptian Globigerinelloides blowi Zone (LC9) in Hole 392A may result from the lack of samples in the interval between Cores 3 and 4 .

\section{REGIONAL CORRELATION}

It is beyond the scope of this study to compare and correlate the Blake Nose (Sites 390, 392) and Blake Bahama Basin (Site 391) foraminifers with Lower Cretaceous assemblages known from earlier studies in North America, such as Texas, Oklahoma (Tappan, 1940, 1943; Loeblich and Tappan, 1949; Frizzel, 1954; Michael, 1972), Trinidad (Barstenstein et al., 1957, 1966, 1973), California (Dailey, 1970, 1973), Scotian and Grand Banks (e.g., Jenkins et al., 1974, Gradstein et al., 1975).

A regional correlation to Deep Sea Drilling Sites $99 \mathrm{~A}, 100,101 \mathrm{~A}$ in the Blake-Bahama Basin and Site 105, in the Hatteras Abyssal Plain (see Figure 1 for location), cannot be made, with one exception. The single direct correlation, as mentioned earlier, is through the interval with Dorothia praehauteriviana Dieni and Massari in Hole 391C (Cores 24, 26) and in Holes 101A (Core 10) and 105 (Cores 19-21) dated Valanginian. Owing to a lack of age-diagnostic species in Holes 99A, 100, 101A, and 105, none of the Barremian-Albian zones and/or assemblages at Sites 390,391 , and 392 can be correlated. The lack of species may be explained by the very deep water, below the CCD, depositional environment.

Hole 101A, Core 4, and Site 105, Cores 11, 12, contain an assemblage with Rotalipora apenninica Renz and Planomalina buxtorfi (Gandolfi). This corresponds to the zone of $P$. buxtorfi- $R$. apenninica (LC19) (van Hinte, 1976) of Vraconian (latest Albian) age. The youngest Lower Cretaceous zone in the Blake Nose sites is UC17, early late Albian.

\section{ACKNOWLEDGMENTS}

I thank the Deep Sea Drilling Project for the opportunity to participate on Leg 44 and the management of the Geological Survey of Canada for permission to spend the time on the cruise and the subsequent onshore study. I extensively used the Geological Survey's technical facilities including the new Cambridge Stereo Scan S-180. The Scanning Electron Microscope illustrations were prepared by P. Girouard, Dartmouth, N. S. Maisie Trapnell typed the manuscript and G. Cook drafted the figures.

Much appreciated help and advice was also provided by $\mathrm{P}$. Ascoli, J. Bujak, and D. Walker, Dartmouth, N. S.; M. A. Buzas and R. Cifelli, United States National Museum (USNM), Washington; H. Bartenstein, Celle; H.P. Luterbacher, Bordeaux; and T. Saito, New York.

\section{APPENDIX}

Stratigraphic list of the taxa occurring in the Lower Cretaceous Sediments of Hole 391C.

Specimens of all taxa are rare (1-9 specimens) unless stated otherwise. 


\begin{tabular}{|c|c|}
\hline $4, \mathrm{CC} ; 5-1,82-84 \mathrm{~cm}$ & Barren \\
\hline $5-1,143-145 \mathrm{~cm}$ & Barren \\
\hline $5, \mathrm{CC}$ & $\begin{array}{l}\text { Uverigerinammina, Plectorecurvoides } \\
\text { (common), Bolivinopsis, } \\
\text { Ammodiscus, Glomospira, } \\
\text { Hormosina, Bathysiphon, } \\
\text { Glomospirella }\end{array}$ \\
\hline $6-2,113-115 \mathrm{~cm}$ & Barren \\
\hline $6-4,52-54 \mathrm{~cm}$ & Barren \\
\hline $6, \mathrm{CC}$ & $\begin{array}{l}\text { Glomospira, Glomospirella, } \\
\text { Plectorecurvoides, Trochammina, } \\
\text { Bathysiphon, ?Textularia, Reophax; } \\
\text { serpulids, fish teeth }\end{array}$ \\
\hline $7, \mathrm{CC}$ & $\begin{array}{l}\text { Barren except for common, pyritized } \\
\text { radiolarians }\end{array}$ \\
\hline $8, \mathrm{CC}$ & $\begin{array}{l}\text { Plectorecurvoides, ?Glomospirella, } \\
\text { Trochammina globigeriniformis, } \\
\text { Trochammina sp. }\end{array}$ \\
\hline $9-1,33-35 \mathrm{~cm}$ & Barren \\
\hline $9-2,48-50$ & Hedbergella spp. \\
\hline $9, \mathrm{CC}$ & Trochammina, ra \\
\hline $10-2,73-74 \mathrm{~cm}$ & Patellina sp., Spirillina, sponge spicules \\
\hline $10-2,105-107 \mathrm{~cm}$ & $\begin{array}{l}\text { Ammobaculites, Glomospira, } \\
\text { Trochammina, ? Spirillina, } \\
\text { ?Hormosina }\end{array}$ \\
\hline$-59 \mathrm{~cm}$ & Glomos \\
\hline & Barren \\
\hline $7 \mathrm{~cm}$ & $\begin{array}{l}\text { Hedbergella trocoidea, } \mathrm{H} \text {. spp., } \\
\text { Globigerinelloides ferreolensis, } \\
\text { Gavelinella aff. intermedia, } \\
\text { Lenticulina, Ostracoda }\end{array}$ \\
\hline 4 & t for pyritized radiolarian \\
\hline & $\begin{array}{l}\text { Gavelinella barremiana, Hedbergella } \\
\text { sigali, Lenticulina crepidularis }\end{array}$ \\
\hline $14-3,149-150 \mathrm{~cm}$ & ?Dorothia, miliolids \\
\hline & $\begin{array}{l}\text { Barren, except for some aptychi and } \\
\text { other ammonite fragments and } \\
\text { pieces of "wood" }\end{array}$ \\
\hline $\begin{array}{l}15-3,143-146 \mathrm{~cm} \\
\text { (thin section) }\end{array}$ & $\begin{array}{l}\text { miliolids, Ophthalmidium, Lenticula, } \\
\text { Epistomina, crinoids, pelecypods, } \\
\text { echinoid, and coral fragments }\end{array}$ \\
\hline 15 , & Barren \\
\hline & Barren \\
\hline $\begin{array}{l}21, \mathrm{CC} ; 22, \mathrm{CC} \text {, and } \\
24-3,14-16 \mathrm{~cm}\end{array}$ & $\begin{array}{l}\text { Dorothia sp. (co), Pseudonodosaria, } \\
\text { Conorboides hofkeri, Lenticulina } \\
\text { nodosa, Vaginulopsis, Eoguttulina, } \\
\text { radiolarians }\end{array}$ \\
\hline $\begin{array}{l}25-1,49-51 \mathrm{~cm}, 25-5 \\
100-112 \mathrm{~cm} ; 25-2, \\
105-107 \mathrm{~cm} ; 26-1, \\
100-102 \mathrm{~cm} ; \text { and } 26-3 \\
60-62 \mathrm{~cm}\end{array}$ & $\begin{array}{l}\text { Radiolarians (common-frequent) } \\
\text { Dorothia prachauteriviana (frequent), } \\
\text { Lenticulina nodosa, Lenticulina } \\
\text { spp. (common), Haplophragmoides; } \\
\text { radiolarians (common) }\end{array}$ \\
\hline
\end{tabular}

Cores 27 through 50 are virtually devoid of foraminifers, except for isolated specimens of Glomospira, Spirillina, Vaginulopsis, and Ophthalmidium. Foraminifers in Cores 50 to 52 have been dated Late Jurassic (see Site 391 Report, this volume).

\section{ANNOTATED LIST OF SELECTED LOWER CRETACEOUS FORAMINIFERS}

(Formal references have been kept to a minimum)

\section{"Globigerina" hoterivica Subbotina}

(Plate 9, Figures 9-15)

Globigerina hoterivica Subbotina, 1953. Fossil foraminifera of the USSR, Globigerinidae, Hantkeninidae, and Globorotaliidae (translated from Russian), Collet's Publ. Ltd., 1971, p. 50, pl. 1, fig. 1-4.

Globigerina kugleri Bolli, 1959, Am. Paleontol. Bull., v. 39, no. 79, p. 27 , pl. 23, fig. 3-5.

About 16 small, very poorly preserved Globigerina-like specimens occur in Section 390-6-1 and Sample 6, CC. Half of these are irregular in shape and are reminiscent of those in rich assemblages of "Globigerina" bathoniana Pazdrowa of Middle Jurassic Grand Banks deposits (Gradstein, 1977), where over half of the specimens are no more than an irregular cluster of chambers. The more regularly structured forms in Section 390-6-1 and Sample 6, CC show the following features: low to medium high trochospire with globular chambers which increase in size slowly; four chambers in the last whorl; aperture arched often with lip; aperture mostly umbilical, rarely umbilical to extra-umbilical; apertural arch varies from less than one-third as high to almost as high as wide. From the description of Globigerina graysonensis Tappan (Tappan, 1940, 1943; Bolli, 1959; Longoria, 1974) and from a comparison to the holo-, para-, and hypotypes in the United States National Museum, Washington, the Blake Nose specimens do not fall within the range of variation of this species. The specimens are more similar to Globigerina kugleri Bolli (Bolli, 1959, and USNM holo- and paratypes; Marianos and Zingula, 1966, USNM hypotype). This species is probably a junior synonym of Globigerina hoterivica Subbotina (often spelled "hauterivica"). Dailey (1973; sub G. hoterivica) includes Globigerina sp. A, Marianos and Zingula, in G. hoterivica but excludes G. kugleri sensu Marianos and Zingula because of a Gubkinella-like medium-high trochospire. From my observation of the USNM hypotype of G. kugleri sensu Marianos and Zingula, I include this specimen in G. hoterivica, which agrees with the variation described by Subbotina $(1953$, p. 53 , fig. 2,3$)$ and also agrees with the variation among Blake Nose specimens. As such $G$. hoterivica resembles $G$. graysonensis, which shows considerable variation in height of the spire (Tappan, 1940, 1943; Bolli, 1959; Longoria, 1974).

G. hoterivica is known from the Hauterivian of the Caucasus (Subbotina, 1953), the Toco and Cuche formations (BarremianAptian) of Trinidad (sub G. kugleri; Bolli, 1959), the Budden Canyon Formation in California (Hauterivian-Barremian range; Marianos and Zingula, 1966; Dailey, 1973), and the lower Aptian of (?) Mexico (Longoria, 1974; sensu Caucasella hauterivica). Luterbacher (1972) found it at DSDP Site 105. According to Michael (1967) it is also known from Northwest Germany. The total range is upper Hauterivian to lower Aptian. Van Hinte (1976) restricts the species to the upper Hauterivian. Also known (sub G. kugleri) from the Neocomian (?Valanginian)-Aptian of the Scotian Shelf (Gradstein et al., 1975; P. Ascoli, personal communication).

\section{Globigerinelloides blowi (Bolli)}

(Plate 9, Figures 5-8)

Planomalina blowi Bolli, 1959, Am. Paleontol. Bull., v. 39, no. 79, p. 260 , pl. 20, fig. 2-6.

Globigerinelloides blowi (Bolli), Moullade, 1966, Doc. Labo. Geol. Fac. Sci. Lyon, no. 15, p. 119-121, pl. 8, fig. 24-26.

First described as Planomalina blowi Bolli from the Aptian Leupoldina protuberans Zone, Cuche Formation, Trinidad (Bolli, 1959). Moullade's (1966) description and figures are particularly close to our specimens. Type specimens of the species in the USNM, Washington, have a more lobate periphery with deeper incised sutures. The stratigraphic range is given as $G$. blowi to $G$. algerianus zones (Aptian; van Hinte, 1976)-only found in Sample 390-5, CC assigned to the lower Aptian G. blowi Zone.

Globigerinelloides ferreolensis (Moullade)

(Plate 9, Figures 1-4; Plate 10, Figures 14-17)

Biticinella ferreolensis Moullade, 1961, Rev. Micropal., v. 3, no. 4, p. 214 , pl. 1, fig. 1-5.

Globigerinelloides ferreolensis (Moullade), 1966, Doc. Labo. Geol. Fac. Sci. Lyon, no. 15, p. 122-124, pl. 9, fig. 1-3.

Common at Sites 390 and 392 (G. algerianus Zone). Specimens have 7-8 chambers in the last whorl; the chamber shape is spherical to slightly ovate; test outline varies from roughly circular to somewhat elliptical. There is a tendency to a "Biglobigerinella" stage in three out of the several dozen specimens examined. The morphology is similar to that in the original figures and description of $G$. ferreolensis by Moullade (1966). Moullade defines the species as having 7-9 chambers in the last whorl with slightly ovate chambers which increase but slowly in size and with a tendency to a "Biglobigerinellid" stage.

From the original descriptions of $G$. ferreolensis and $G$. barri the two species seem to overlap morphologically. G. barri has 8-10 ovate 
to nearly circular chambers, circular test outline (Bolli, Loeblich, and Tappan, 1957, p. 25, pl. 1, fig. 13-18b) or globular chambers with common "Biglobigerinellid" stage (Longoria, 1974). Longoria restricts $G$. ferreolensis to specimens with 7-9 globular chambers, ovate test outline, and no paired final chamber.

\section{Globigerinelloides aff. saundersi (Bolli)} (Plate 10, Figure 4)

Planomalina saundersi Bolli, 1959, Am. Paleontol. Bull., v. 39, no. 79, p. 262 , pl. 20 , fig. $9-11$.

Globigerinelloides saundersi (Bolli), Longoria, 1974, Rev. Esp. Micropal. num. extra., p. 88, 89, pl. 3, fig. 2, 6-12; pl. 9, fig. 8, 9.

Three specimens in Sample 392A-3, CC, (?S. cabri-) G. algerianus Zone, which have 6-8 rather than 4-6 chambers in the last whorl as defined by Bolli (1959; see also Longoria, 1974).

\section{Hedbergella amabilis Loeblich and Tappan (Plate 11, Figures 11-13)}

Hedbergella amabilis Loeblich and Tappan, 1961, Micropal., v. 7, no. 3 , p. 274 , pl. 3, fig. 1-10.

Flat trochospire, open umbilicus; smooth-walled, finely perforate chambers laterally somewhat flattened; sutures distinct, often constricted, giving rise to strongly lobate periphery; usually 6 , rarely 5 or 7 chambers in the last whorl; last chambers often elongated. In the Blake Nose specimens there is a variation of specimens with little elongation of the last chamber to much elongated last chamber(s). Specimens transitional between $H$. amabilis and $H$. planispira (Tappan) are also present. Loeblich and Tappan (1961) reported this species from Cenomanian sediments in submarine Core A167-25 from the Blake Plateau. Pessagno (1967) gives a range from Cenomanian-Coniacian. On the Blake Nose, present in the $T$. breggiensis Zone.

\section{Hedbergella planispira (Tappan)}

(Plate 11, Figures 14-16)

Globigerina planispira Tappan, 1940, J. Paleontol., v. 14, no. 2, p. 122, pl. 19, fig. 12.

Hedbergella planispira (Tappan), Longoria, 1974, Rev. Esp. Micropal. num. extra., p. 64-65, pl. 11, fig. 4-16; pl. 20, fig. 4; pl. 23 , fig. $1-7,11-13,17-18$; pl. 24 , fig. 10 .

Outline circular to slightly oval; the few whorls occur in a flat coil; mostly 6 to 8 chambers in the last whorl; chambers of subglobular to globular shape, increasing slowly in size; wide umbilicus. During a visit to the USNM, Washington, I compared specimens to the holoand paratypes by Tappan (1940; sub Globigerina planispira) from the Grayson Formation, Texas, to hypotypes from the Duck Creek Formation (Tappan, 1943) and to Praeglotruncana planispira (Tappan) and Praeglobotruncana modesta Bolli $(=H$. planispira, see Loeblich and Tappan, 1961, p. 26) from the Maridale Formation, Trinidad (Bolli, 1959)

Cenomanian $H$. trocoidea (Gandolfi) identified by Loeblich and Tappan (1961) from submarine Core A167-25 on the Blake Plateau was incorporated in $H$. planispira by Pessagno (1967; see also Michael, 1972, p. 211).

\section{Hedbergella aff. trocoidea (Gandolfi)} (Plate 10, Figures 7, 8)

Anomalina lorneiana d'Orbigny var. trocoidea Gandolfi, 1942, Riv. Ital. Paleontol., v. 48, no. 4, p. 98, pl. 2, fig. 1; pl. 4, fig. 2, 3; pl. 13, fig. 2-5.

Hedbergella trocoidea (Gandolfi) Longoria, 1974, Rev. Esp. Micropal. num. extra., p. 69-72, pl. 17, fig. 1-16; pl. 18, fig. 3-5. Several specimens in Sample 390-3-3, 80-82 cm (Ticinella primula Zone) which resemble the species sensu stricto as found in large numbers in the Globigerinelloides algerianus Zone in Holes 390, 392A. However, the specimens lack the densely pustulose, beaded wall and have more constricted sutures.

\section{Benthic Foraminifers}

\section{Conorboides hofkeri (Bartenstein and Brand)} (Plate 1, Figure 15)

Conorbis hofkeri Bartenstein and Brand, 1951, Verh. Senckenb. Naturf. Ges., 485, p. 325, 326, pl. 11, fig. 320.
Conorboides hofkeri (Bartenstein and Brand), Dieni and Massari, 1966, Palaeont. Ital., v. 61, p. 176, pl. 8, fig. 22.

Isolated and poorly preserved, recrystallized (pyritized) individuals in Sample $391 \mathrm{C}-24-3,14-16 \mathrm{~cm}$. The generic concept follows Loeblich and Tappan (1964) and Pazdro $(1969$, p. 20) with the characteristic open umbilicus, looping or non-looping umbilical apertures with little incision in the chamber walls, rapidly enlarging chambers and flat or concave umbilical side. Those features are more or less visible in Plate 1, Figure 15. Known from BerriasianValanginian strata (e.g., see Simon and Bartenstein, 1962; Dieni and Massari, 1966; Bartenstein, 1976b); also known from the Neocomian of the Canadian Atlantic margin (Gradstein et al., 1975). The occasional occurrence (?reworked) on the Scotian Shelf, Canada, in Barremian sediments (P. Ascoli, personal communication) needs further study.

\section{Epistomina chapmani Ten Dam}

(Plate 8, Figure 5)

Epistomina chapmani Ten Dam, 1948, Rev. Inst. Franc. Petr., v. 3, p. 166, pl. 1, fig. 5. Ohm, 1967, Palaeontographica, Bd. 127A, p. 144, pl. 19 , fig. 8,11 ; text-fig. 39 .

A dozen or more specimens of a smooth-walled Epistomina occur in Hole 392 in the Ticinella primula-T. breggiensis zones. The umbilical side is more convex than the spiral side, there are 5-6 chambers in the last whorl. Three specimens are round in outline and keeled, the others are more lobate and non-keeled. Sutures are flush to slightly depressed and curved backward slightly; the chamber walls have a discontinuous pore pattern as often occurs in E. supracietacea Ten Dam and E. elegans (d'Orbigny). The dental apertures are discontinuous rather than continuous along the periphery as in $E$. caracolla and $E$. supracretacea (see Ohm, 1967) and close to the periphery. There is no umbo as is always present in $E$. caracolla (Roemer). The specimens are identified as E. chapmani Ten Dam known from the middle Barremian-Albian of Europe (incl. USSR) and California (Ohm, 1967; Dailey, 1973). The original description by Ten Dam mentions 8 chambers in the last whorl; Ohm illustrates specimens with 7 chambers. Pyritized specimens identified as E. chapmani by P. Ascoli from the Scotian Shelf Lower Cretaceous (P. Ascoli, personal communication) show a variation of 6-9 chambers in the last whorl.

\section{Epistomina cretosa Ten Dam}

(Plate 8, Figures 3, 4)

Epistomina cretosa Ten Dam, 1947, Geol. Mijnb., v. 8, no. 2, p. 29 , fig. 6. Ohm, 1967, Palaeontographica, Bd. 127A, p. 148, pl. 20, fig. 2 , text-fig. 43.

Known from upper Hauterivian through Albian strata $(\mathrm{Ohm}$, 1967), but at the Blake Nose only found in Albian beds at Site 392 . Grand Banks specimens from the Amoco IOE Puffin B-90 well (Jenkins et al., 1974) are less stoutly built and have less curved sutures than the ones from the Blake Nose.

\section{Epistomina ornata (Roemer)}

(Plate 4, Figure 11)

Planulina ornata (Roemer), 1841, Kreidegebirge, p. 98, pl. 15, fig. 25. Epistomina ornata (Roemer), Ohm, 1967, Palaeontographica, Bd. 127 A, p. 135 , pl. 3 , fig. $1-2$; pl. 5 , fig. 7.

The Blake Nose specimens in Hole 390, Core 6 (Barremian) compare well with the specimens of this species from the Cuche Formation, Trinidad present in the USNM, Washington (Bartenstein et al., 1957). Its range seems to be upper Valanginian-lower Barremian as first established in West German localities. In Trinidad it occurs as high as middle Barremian (see Bartenstein et al., 1957; Simon and Bartenstein, 1962; Ohm, 1967; Dailey, 1973). In the Canadian Atlantic Shelf it is used as a Neocomian-Barremian marker in the Verrill Canyon Formation (Gradstein et al., 1975).

\section{Gavelinella-Lingulogavelinella}

Eighteen samples in Holes 390, 390A, and 392A, belonging in the $G$. barremiana/L. sigali to $T$. breggiensis zones (Barremian-upper Albian), contain rare to frequent occurrences of specimens of several taxa of gavelinellids; some of the gavelinellids have been assigned to genera and species described in the literature. 
Gavelinella barremiana

(Plate 6, Figures 14-17)

Gavelinella barremiana Bettenstaedt, 1952, Senckenb., v. 33, p. 275, 276, pl. 2, fig. 26-29. Michael, 1966, Senckenb. Leth., v. 47, no. $5 / 6$, p. $430-432$, pl. 50 , fig. $1-3$.

In Samples 390-5, CC, 390-6-1, and 392A-4-1, 110-112 cm (G. barremiana- $L$. sigali Zone) specimens are relatively small (less than $250 \mu \mathrm{m}$ in diameter) and mostly flat or slightly convex; the sutures curve backward; the apertural side is involute with a narrow, mostly open umbilicus; the spiral, aboral side is evolute. Many specimens have slender tongue-like apertural flaps reaching over the umbilical suture; these are faintly visible in Plate 6, Figures 14, 17. From a comparison with the detailed description by Michael (1966) the specimens clearly belong in Gavelinella barremiana Bettenstaedt. According to Michael (1966) (see also Bartenstein, 1976b), the species is cosmopolitan and ranges from middle-upper Barremian, with forms transitional to G. intermedia in lower Aptian. Van Hinte (1976) restricts the species to the Barremian. Also known from the Cuche Formation (Barremian) in Trinidad (Bartenstein et al., 1957) and the Scotian Shelf and Grand Banks (Gradstein et al., 1975) where it is used as a Barremian (-lower Aptian) marker.

"Gavelinella" sp. A-C, G. intermedia (Berthelin) and G. intermedia (Berthelin)-G. ammonoides (Reuss)

In 15 samples in Holes 390,390A, and 392A, assigned to the $G$. blowi through $T$. breggiensis zones, gavelinellids which show considerable and rather continuous variation in morphology occur rarely to frequently.

Gavelinella intermedia (Berthelin) is probably one of the more common forms. Other closely related specimens show features of such recently proposed genera as Lingulogavelinella and Orithostella (sensu Eicher and Worstell, 1970; Scheibnerova, 1971, 1974).

Because of the wide, rather continuous variation and absence of clear stratigraphic trends in the forms observed. I do not deem it useful, in this preliminary account to split this group into formal taxa. Also, there is no common opinion on the ranking of characters (if possible at all) to define such genera as Gavelinella, Lingulogavelinella, and Orithostella (compare Michael, 1966; Malapris-Bizouard, 1967; Scheibnerova, 1971, 1974; and Eicher and Worstell, 1970) and on the species level there are many potential synonyms in European and American literature. For these reasons I prefer to describe the variation without drawing detailed taxonomic conclusions. In order to draw such conclusions, a comparison to types and variations of established taxa is desirable.

On the distribution charter of Figures 2 and 3, specimens of Gavelinella sp. A-C, G. intermedia, and $G$. intermedia-ammonoides have been referred to as " $G$." intermedia group; data on distribution of individual members of this group are in the text.

Gavelinella sp. A

(Plate 5, Figures 1-7, 10-12)

Relatively large (up to $500 \mu \mathrm{m}$ in diameter), low trochospiral, flat or low biconvex to plano- or concavoconvex specimens with 8-10 narrow chambers in the last whorl. Sutures curve strongly backward, and may be partially limbate, but more often are slightly depressed; chamber wall is coarsely perforated. The aboral side is partially to fully evolute, and in the younger samples may show an imperforate boss; the oral side is more involute with a wide, shallow umbilicus; the aperture is a narrow slit at the base of the last chamber, reaching from over the subacute periphery to the relative involute (oral) side and continuing along the umbilical suture. Most specimens have distinct, tongue-like, apertural flaps which reach into the umbilicus and overlap each other in an imbricate manner, going backward along the suture; there is some variation in the shape and size of these flaps; the flaps are less perforate than the rest of the test or imperforate (Plate 5, Figure 4). Found in Sample 390-5-2, 60-62 cm (G. algerianus Zone) and $392 \mathrm{~A}-2-1,86-89 \mathrm{~cm}, 392 \mathrm{~A}-2-2,146-148 \mathrm{~cm}$, $392 \mathrm{~A}-2-3,104-106 \mathrm{~cm}, 392 \mathrm{~A}-2, \mathrm{CC}$, and $392 \mathrm{~A}-3-1,46-48 \mathrm{~cm}(T$. primula and $T$. breggiensis zones).

Except for the larger size of the test, many of these specimens resemble $G$. barremiana as present in underlying samples which may have been ancestral to Gavelinella sp. A. Compare Plate 5, Figure 5 and Plate 6, Figure 17.
Gavelinella intermedia (Berthelin)

(Plate 6, Figures 5-13; Plate 7, Figure 13)

Anomalina intermedia Berthelin, 1880, Mem. Soc. Geol. France, v. 3 , no. 1 , p. 67 , pl. 4 , fig. 14 ;

Gavelinella intermedia (Berthelin), Michael, 1966, Senckenb. Leth., v. 47 , no. $5 / 6$, p. $432-434$, pl. 50 , fig. 4-13.

Gavelinella sp. A grades into a group of specimens with a more convex oral side and often less developed tongue-like imperforate flaps, especially in those (small) specimens with limbate sutures. The aboral side may have an imperforate boss. These specimens compare with Gavelinella intermedia (Berthelin) as described by Michael (1966; see also Scheibnerova, 1974). The taxon is most common in Sample $390-5-1,87-89 \mathrm{~cm}$, and also in $392 \mathrm{~A}-2, \mathrm{CC}, 392 \mathrm{~A}-3-3,50-52 \mathrm{~cm}(G$. algerianus- $T$. breggiensis zones).

In Sample 390A-14-5, 119-121 cm and 390A-14, CC and also in $390-3-3,80-82 \mathrm{~cm}$ ( $T$. primula Zone) many specimens assigned to the $G$. intermedia group are relatively tightly asymmetricallysymmetrically coiled, and have a broadly rounded periphery (Plate 6 , Figures 11, 12) and small apertural flaps (when visible).

\section{Gavelinella sp. B}

(Plate 5, Figure 8)

A third group present with rarely occurring individuals in Samples $390-5-1,87-89 \mathrm{~cm}, 390-2-3,80-82 \mathrm{~cm}$, and possibly in 392A3 , CC ( $G$. algerianus- $T$. breggiensis zones) shows a markedly flat to concave oral side, no limbate sutures and larger tongue-like flaps than Gavelinella sp. A. The flaps reach more than halfway along the chamber sutures, rarely observed in Gavelinella sp. A. The flaps are largely imperforate.

In 392A-3, CC some symmetrically biconvex specimens are possibly related to this form and resemble Orithostella indica Scheibnerova from the Albian of the Eastern Indian Ocean (DSDP Leg 27) (Scheibnerova, 1974).

\section{Gavelinella sp. C}

(Plate 7, Figures 14-16)

A fourth group, Gavelinella sp. C, is present in Samples 390A-14, CC, 392A-2-1, 84-86 cm, 392A-2, CC, and 392A-3-1, 46-48 cm (T. primula Zone). All specimens (rare to common) have a flat to low convex, rather evolute, oral side and usually a fully involute and almost always more convex aboral side. The umbilicus is generally very narrow. Some specimens are strongly planoconvex. There is a limbate spiral suture; no distinct apertural flaps were observed. In the more planoconvex specimens the sutures are more curved backward, often with a sudden turn halfway. Gavelinella sp. C and more tightly coiled members of Gavelinella intermedia, as in Sample 390A-14, CC, may be the same taxon.

\section{Gavelinella intermedia-ammonoides (Reuss) \\ (Plate 6, Figures 1-4)}

In Samples 390-5-1, 87-89 cm, 390-3, CC, 392A-2-3, 104-106 cm, and $392 \mathrm{~A}-3, \mathrm{CC}$ (G. algerianus- $T$. breggiensis zones) there are rare, fairly small Gavelinella-type specimens in which the younger chambers of the last whorl increase considerably in width. The test is asymmetrically-symmetrically biconvex, with the spiral side often flatter. The aperture occurs on the umbilical side with a narrow lip. The umbilicus is narrow.

The specimens tend to G. ammonoides (Reuss) which according to Michael (1966) originated from $G$. intermedia in middle Albian time. Variants of $G$. barremiana and $G$. intermedia resembling $G$. ammonoides, also occur stratigraphically lower. In Samples 390-5-1, 87-89 $\mathrm{cm}$ and 392A-3, CC the specimens intergrade with $G$. intermedia.

G. ammonoides occurs in the middle Albian-?Turonian of Europe (Michael, 1966). Bartenstein and Bolli (1973) list it as probably present in upper Aptian-lower Albian beds in Trinidad.

\section{Lingulogavelinella ciryi Malapris-Bizouard} (Plate 5, Figures 9, 13-17)

Lingulogavelinella ciryi ciryi Malapris-Bizouard, 1967, Rev. Micropal., v. 10 , no. 2, p. 137,138 , pl. 1 , fig. 16-19; pl. 2, fig. 1620 
L. aff. ciryi ciryi Malapris-Bizouard, Maync, 1973, Init. Rept. DSDP Leg 13, p. 1099, pl. 4, fig. 6-11.

In Samples $392 \mathrm{~A}-2-2,146-148 \mathrm{~cm}$ and $392 \mathrm{~A}-3-1,46-48 \mathrm{~cm}(T$. primula- $T$. breggiensis zones) there are some specimens of a tiny gavelinellid (less than $300 \mu \mathrm{m}$ in diameter) which differ from other gavelinellids in the samples by its small size, low asymmetrically biconvex test, and rounded periphery. It has 7-8 chambers in the last whorl. Two specimens show sigmoid sutures with small crenulations in the last chambers (Plate 5, Figure 14). Imperforate apertural flaps, which may be triangular in shape (Plate 5, Figure 13) are well developed.

From the detailed description by Malapris-Bizouard (1967) we may be dealing with Lingulogavelinella ciryi known from the Albian (including Vraconian) of France and also mentioned by Maync (1973) in Albian beds in DSDP Site 120 on Gorringe Bank, North Atlantic Ocean.

\section{Plexus of Gaudryina dividens Grabert-Spiroplectinata lata Grabert} (Plate 2, Figures 1-18)

Gaudryina dividens Grabert, 1959, Abh. Senckenb. Naturf., Ges. 498, p. 9-11, pl. 1, fig. 35 ; pl. 2, fig. 16-30; pl. 3, fig. 53-59.

Gaudryina dividens var. compacta Grabert. G. compacta Grabert, 1959, Abh. Senckenb. Naturf., Ges. 498, p. 11, pl. 1, fig. 6-8; pl. 3, fig. 48-52.

Gaudryina dividens var, reicheli Bartenstein, Bettenstaedt, and Bolli. $G$. reicheli Bartenstein, Bettenstaedt, and Bolli, 1966, Eclog. Geol. Helv., v. 59, no. 1, p. 142, 143, pl. 1, fig. 34-37, 50-55. Bartenstein and Bolli, 1973, Eclog. Geol. Helv., v. 66, no. 2, p. 396, pl. 2, fig. 36-51. Spiroplectammina californica Dailey, 1970. Contrib. Cushm. Found. Foram. Res., v. 21, pt. 3, p. 104, pl. 11, fig. 7, 8.

Spiroplectinata lata Grabert, 1959, Abh. Senckenb. Naturf., Ges. 498, p. 16 , pl. 1, fig. 9 , pl. 2, fig. $31-35$, pl. 3 , fig. 60-76.

In the 13 Blake Nose samples belonging to the $G$. algerianus- $T$. primula zones (upper Aptian-middle Albian) rare to frequent Gaudryina and Spiroplectinata occur which are widely varied in morphology and in size. Tests are triserial, triserial-biserial, or triserial-biserial-uniserial; the triserial portion, which is triangular in outline, may be greatly shortened and its sides may be strongly depressed. The biserial portion is also of variable length and may be roughly triangular to trapezoidal or rectangular, with parallel margins or strongly flattened and with diverging margins (flabelliform). Some specimens, especially in Sample 392A-3, CC have more rounded biserial chambers. Chambers of a uniserial part of the test are rounded in outline; the aperture is terminal in the form of a small, elongate or "circular" opening. The wall is composed of minute carbonate particles, including many nannofossils (Plate 2, Figure 3); there are scattered, relatively large pores in the wall.

The USNM types in Washington and description of Gaudryina subcretacea Cushman and G. alexandri Cushman from the upper Lower Cretaceous, Duck Creek Formation (Texas, Oklahoma) do not fully compare with the Blake Nose specimens. G. subcretacea has a more flattened, triserial portion (see also Tappan, 1943, p. 490, pl. 78 , fig. 28,29 ) and might be a stunted and diagenetically flattened $G$. alexandri. $G$. alexandri differs from the Blake Nose specimens because of its more pronounced and sharper triserial and biserial periphery (see also Grabert, 1959, p. 10,11, 45, 46).

From the detailed description and illustrations by Grabert, 1959 (see also Simon and Bartenstein, 1962, p. 285, 286) the Blake Nose specimens fall within the plexus of Gaudryina dividensSpiroplectinata of Aptian-Albian age. This plexus, which in northwestern Europe includes several Gaudryina and Spiroplectinata species, shows a strong reduction of the triserial part through time and also a progressive increase in the flat biserial stage of the test. From a comparison to the literature, the Blake Nose specimens may be divided into approximately four typological taxa (abbreviated in Figures 2 and 3 as " $G$. dividens group").

Many specimens which are either triserial, triserial-biserial, or triserial-biserial-uniserial with a relatively long triserial part with strongly depressed sides and a roughly triangular to trapezoidal or rectangular outline of the biserial portion (Plate 2, Figures 9-13, 1618) belong in Gaudryina dividens Grabert. Specimens with less depressed sides of the triangular portion (Plate 2, Figures 12,13) have been described by Grabert (1959) as the variant $G$. compacta. Some specimens, especially in Samples 392A-3, CC and in 390-5-1, 87-89 $\mathrm{cm}$ (both upper Aptian) have more rounded biserial chambers and resemble G. reicheli Bartenstein, Bettenstaedt, and Bolli (Plate 2, Figures 14, 15) from the Aptian-lower Albian of Trinidad and possibly California (cf. Spiroplectinata californica Dailey; see Bartenstein et al., 1966; Bartenstein and Bolli, 1973; Dailey, 1970, 1973). Isolated specimens in Sample 392A-3-1, 46-48 cm (T. primula Zone, middle Albian) and over one hundred specimens in Samples $390-5-1,87-89 \mathrm{~cm}, 392 \mathrm{~A}-3-3,50-53 \mathrm{~cm}$ and $392 \mathrm{~A}-3, \mathrm{CC}$ (all belonging in the upper Aptian [S. cabri-] G. algerianus Zone) possess a strongly reduced triserial, depressed triangular test, and an often long biserial part with moderately to strongly flattened chambers much wider than high and rarely a uniserial test portion (Plate 2, Figures 1-8). Such specimens belong in Spiroplectinata and have been identified as $S$. lata, first described by Grabert from the lower-middle Albian of Germany where it originated from $G$. dividens. The Blake Nose Spiroplectinata lata specimens are readily separable from Gaudryina type one, with few transitional individuals.

Table 2, shows, in descending stratigraphic order, the number of specimens of this Gaudryina-Spiroplectinata plexus per sample at Site 390 (Holes 390, 390A) with triserial, triserial-biserial, or triserialbiserial-uniserial tests. The tabulation does not show a trend in time toward reduction of the triserial part, or an increase in the length of the biserial portion (Grabert, 1959).

In order to arrive at a more meaningful phylogenetic analysis, we need to eliminate the ontogenetic effect on the test-building plan. This requires more material so that we can analyze the phylogenetic trend on specimens which have reached a certain ontogenetic stage.

Table 3 shows the stratigraphic distribution of the four taxa recognized in the Blake Nose sites. It fails to show the postulated trend in time of Gaudryina (G.)-Spiroplectinata (S.).

TABLE 2

Number of Specimens of the Gaudryina-Spiroplectinate Plexus per Sample in Holes 390 and 390A

\begin{tabular}{|c|c|c|c|c|c|}
\hline Comments & $\begin{array}{c}\text { Sample } \\
\text { (Interval in } \mathrm{cm} \text { ) }\end{array}$ & Triserial & $\begin{array}{l}\text { Numbe } \\
\begin{array}{c}\text { Triserial- } \\
\text { Biserial }\end{array}\end{array}$ & $\begin{array}{l}\text { of Specime } \\
\text { Triserial- } \\
\text { Biserial- } \\
\text { Uniserial }\end{array}$ & Total \\
\hline 1-3 biserial pairs & $390 \mathrm{~A}-14-5,119-121$ & 7 & 21 & 4 & 32 \\
\hline $\begin{array}{l}4 \text { specimens strongly } \\
\text { lattened biserial pairs } \\
\text { and reduced triserial } \\
\text { pairs }\end{array}$ & $390 \mathrm{~A}-14, \mathrm{CC}$ & 3 & 10 & 3 & 16 \\
\hline 1-5 biserial pairs & $\begin{array}{l}390-3-3,80-82 \\
390-3, \mathrm{CC} \\
390-4-2,75-77 \\
390-4, \mathrm{CC}, 7-9 \\
390-4, \mathrm{CC}\end{array}$ & $\begin{array}{l}8 \\
2 \\
2\end{array}$ & $\begin{array}{r}27 \\
3 \\
4 \\
1\end{array}$ & $\begin{array}{r}2 \\
10 \\
3\end{array}$ & $\begin{array}{r}37 \\
14 \\
7 \\
3 \\
2\end{array}$ \\
\hline $\begin{array}{l}\text { 1.7 pairs biserial, } \\
\text { relatively flat; } \\
\text { reduced triserial part } \\
\text { ( } 38 \text { specimens) }\end{array}$ & $390-5-1,87-89$ & 3 & 40 & 5 & 48 \\
\hline $\begin{array}{l}\text { reduced triserial, } \\
\text { flat biserial part }\end{array}$ & $390-5-2,60-62$ & & & 1 & 1 \\
\hline
\end{tabular}

TABLE 3

Stratigraphic Distribution of the Four Taxa Recognized From Holes 390 and 390A (Blake Nose)

\begin{tabular}{|c|c|c|}
\hline Sample & Location & Taxa \\
\hline $390-3-3,80-82 \mathrm{~cm}$ & Middle Albian & G. dividens var. compacta \\
\hline $390-3, \mathrm{CC}$ & Middle Albian & G. dividens \\
\hline $390-4-2,75-77 \mathrm{~cm}$ & Middle Albian & G. dividens \\
\hline $390-4, \mathrm{CC}, 7-9 \mathrm{~cm}$ & Middle Albian & G. dividens var. compacta \\
\hline $390-4, \mathrm{CC}$ & Middle Albian & G. dividens \\
\hline $390-5-1,87-89 \mathrm{~cm}$ & Upper Aptian & $\begin{array}{l}\text { G. dividens, } G \text {. dividens var. } \\
\text { reicheli, } S \text {. lata* }\end{array}$ \\
\hline $390-5-2,60-62 \mathrm{~cm}$ & Upper Aptian & S. lata \\
\hline $390 \mathrm{~A}-14-5,119-121 \mathrm{~cm}$ & Middle Albian & $\begin{array}{l}\text { G. dividens, } G \text {. dividens var. } \\
\text { compacta* }\end{array}$ \\
\hline $390 \mathrm{~A}-14, \mathrm{CC}$ & Middle Albian & G. dividens*, S. lata \\
\hline $392 \mathrm{~A}-2-1,84-86 \mathrm{~cm}$ & Middle Albian & G. dividens \\
\hline $392 \mathrm{~A}-2-2,146-148 \mathrm{~cm}$ & Middle Albian & G. dividens var. compacta \\
\hline $392 \mathrm{~A}-3-1,46-48$ & Middle Albian & G. dividens $*+S$. lata \\
\hline $392 \mathrm{~A}-3-3,50-52 \mathrm{~cm}$ & Upper Aptian & $\begin{array}{l}\text { G. dividens, } G \text {. dividens var. } \\
\text { compacta* }\end{array}$ \\
\hline $392 \mathrm{~A}-3, \mathrm{CC}$ & Upper Aptian & S. lata, G. dividens var, reicheli* \\
\hline
\end{tabular}

Note: If more than one species occurs in sample, the predominate taxon is marked with an asterisk. 
The presence of more $S$. lata-type specimens in the upper Aptian than in the Albian deposits suggests that the phylogenetic trend of Gaudryina dividens to Spiroplectinata spp. is more complicated than previously suggested. More detailed study, including a direct comparison to material from northwestern European localities, is desirable.

\section{Lenticulina (Planularia) crepidularis (Roemer)}

(Plate 4, Figure 9; Plate 1, Figure 12)

Planularia crepidularis N. Roemer, 1842, Neue Kreide-Form., p. 273, pl. 7B, fig. 4.

Lenticulina (Astacolus) crepidularis (Roemer), Bartenstein, Bettenstaedt, and Bolli, 1957, Eclog. Geol. Helv., v. 50, p. 29, 30, pl. 3 , fig. 55 , pl. 4 , fig. 82,83 .

This species is cosmopolitan and long ranging, but locally more common in the upper Valanginian-lower Barremian sediments (Simon and Bartenstein, 1962). It is also known from the Cuche Formation in Trinidad (Bartenstein et al., 1957) stratigraphically not higher than Barremian and on the Canadian Atlantic Shelf in the Verrill Canyon Formation where it is used as a Neocomian marker (Gradstein et al., 1975). At Sites 390, 391, and 392, it only occurs in the Barremian Zone of G. barremiana-L. sigali.

\section{Lenticulina ex. gr. ouachensis Sigal}

(Plate 4, Figures 4, 8):

Cristellaria ouachensis Sigal, 1952, XIX Congr. Geol. Intern. Monogr. Region (1), no. 26 (Alger), p. 16, fig. 10.

Lenticulina (Lenticulina) ouachensis ouachensis (Sigal), Bartenstein, Bettenstaedt, and Bolli, 1957, Eclog. Geol. Helv., v. 59, no. 1, p. 25,26 , pl. 3 , fig. 50 ; pl 4 , fig. 71,76 .

This includes a few specimens in the zones of $G$. barremiana/ $L$. sigali and $G$. blowi (Barremian-lower Aptian) which show some variation in the extent of the umbilical collar. Specimens with a wide umbilical collar compare to specimens of $L$. ouachensis-ouachensis in the USNM, Washington, from the Cuche Formation, Trinidad (Bartenstein et al., 1957). The cosmopolitan species with its subspecies occurs in Valanginian to Aptian beds (Simon and Bartenstein, 1962; Sigal, 1965; Moullade, 1966; Dailey, 1973; Luterbacher, 1975). It has also been found at DSDP Sites 120 on Gorringe Bank off Portugal (Maync, 1973), 105, Hatteras Abyssal Plain (Luterbacher, 1972), and from the Canadian Atlantic Shelf (Gradstein et al., 1975).

\section{(Marginulopsis) sigali Bartenstein, Bettenstaedt, and Bolli} (Plate 4, Figures 5-7)

Marginulopsis djaffaensis Signal, 1952, XIX Congr. Geol. Intern. Monogr. Region (1?, no. 26 (Alger), p. 15, fig. 9.

Lenticulina (Marginulopsis) sigali Bartenstein, Bettenstaedt, and Bolli, 1957, Eclog. Geol. Helv., v. 57, no. 1, p. 32, 33, pl. 5, fig. 99; pl. 6 , fig. $130,121 . c$

An easily recognizable species which occurs in small numbers in Sites 390 and 392 where it defines the Barremian zone of $G$. barremiana- $L$. (M.) sigali. A paratype of this species in the USNM, Washington, from the Cuche Formation, Trinidad (Bartenstein et al., $1957)$ is very similar to some of the more slender specimens in Sample 392A-4, CC.

Lenticulina (Marginulopsis) sigali was first described as Marginulopsis djaffaensis from the

Lenticulina (Marginulopsis) sigali was first described as Marginulopsis djaffaensis Sigal from the Hauterivian and Barremian of Algeria (Sigal, 1952, 1965) and emended as Lenticulina (Marginulopsis) sigali Bartenstein, Bettenstaedt, and Bolli (1957). These authors and Moullade (1966, sub Marginulina djaffaensis) also give its range from Hauterivian-Barremian. Also known from Germany (Bartenstein et al., 1957), ?California (sub Astacolus schreiteri [Eichenberg]; Daily, 1973£; and the Scotian Shelf of Canada (P. Ascoli, personal communication).

\section{Osangularia utaturensis (Sastri and Sastry)}

(Plate 7, Figures 5-12)

Eponides utaturensis Sastri and Sastry, 1966, Geol. Surv. India Rec., v. 94, p. 292, pl. 19, fig. 6.

Osangularia sp. aff. brotzeni (Gandolfi), Moullade, 1966, Doc.
Labo. Geol. Fac. Sci. Lyon, no. 15, p. 77-79, pl. 1, fig. 9-11, textfig. 2.

Osangularia californica Dailey, 1970, Contrib. Cush. Found. Foram. Res., v. 21, pt. 3, p. 108, 109, pl. 13, fig. 3, 4.

Osangularia utaturensis (Sastri and Sastry), Scheibnerova, 1974, Initial Rept. DSDP Leg 27, p. 714, pl. 4, fig. 27, 28; pl. 5, fig. 1-9; pl. 11 , fig. 4,5 .

Osangularia utaturensis (sub Eponides utaturensis Sastri and Sastry, 1966) was originally described from the Utatur Formation, Madras, India, in beds regarded as upper Albian. Scheibnerova (1974) gives a detailed description, records it from DSDP Leg 27, eastern Indian Ocean, and mentions its presence in northern Australian strata. She regards the Aptian-Albian species $O$. californica Daily (1970) from the Budden Canyon Formation, California, as a junior synonym of $O$. utaturensis. Luterbacher (1975) recently reported $O$. californica from the northwestern Pacific, DSDP Site 305, Leg 32.

Blake Nose specimens identified as this species closely adhere to Scheibnerova's (1971) detailed description. In Sample 390-4-2, 75-77 $\mathrm{cm}$, rather flat instead of planoconvex specimens with a lobate rather than a more circular outline and with flaring chambers also occur (Plate 7, Figure 9).

From the figures and description of Osangularia sp. aff. brotzeni (Gandolfi) in Moullade (1966), the form and O. utaturensis might be the same species. Moullade (1966) gives a range for $O$. sp. aff. brotzeni from uppermost Aptian-middle Albian in the "Fosse vocontienne," southeast France. On the Blake Nose at Sites 390 and $392 O$. utaturensis occurs in the $G$, algerianus- $T$. breggiensis zones (upper Aptian-upper Albian). It is especially common in the Blake Nose Albian strata.

\section{Osangularia insigna Dailey}

(Plate 7, Figures 1-4)

Osangularia insigna Dailey, 1970, Contrib. Cush. Found. Foram. Res., v. 21 , pt. 3, p. 109, pl. 13, fig. 5; pl. 14, fig. 1. O. insigna secunda Dailey, 1970, Ibid., p. 109, pl. 14, fig. 2.

Specimens assigned to this species (incl. O. insigna secunda Dailey, 1970) are mostly about half the size of $O$. utaturensis. Diagnostic features are the mostly symmetrical biconvex test, the large umbilical boss and the weakly curved sutures. There are 10-12 chambers in the last whorl. Dailey (1970) describes the species from the upper AlbianCenomanian of California (Budden Canyon Formation). In Hole $392 \mathrm{~A}$, Blake Nose, it ranges through the zones of $T$. primula- $T$. breggiensis (middle-upper Albian).

\section{Orthokarstenia shastaensis Dailey \\ (Plate 3, Figures 1-4)}

Orthokarstenia shastaensis Dailey, 1970, Contrib. Cush. Found.

Foram. Res., v. 21 , pt. 3, p. 107, pl. 12, fig. 8-10.

Test elongate; short initial triserial part is followed by one pair of biserial chambers in turn followed by up to five uniserial chambers which slowly increase in size; sutures are constricted; the calcareous perforate wall is finely spinose to papillate except often along the sutures which are smooth. The aperture is a rounded or elliptical opening on a short neck.

Dailey (1970) mentions the absence of a tooth plate, but assumes this to be a result of poor preservation. The Blake Nose specimens also lack a clear tooth plate, but in the aperture, remnants of some kind of tooth-plate-like structure seem present (Plate 3, Figures 3,4). The Blake Nose specimens differ from the ones in the Budden Canyon Formation in having a finely spinose to papillate, rather than smooth to papillate wall; but this difference may relate to preservation.

Bartenstein and Bolli (1973, p. 414) erroneously placed $O$. shastaensis in synonymy of Bigenerina clavellata Loeblich and Tappan. The species also occurs in Trinidad (H. Bartenstein, personal communication).

In California, $O$. shastaensis is known from the Aptian through Cenomanian sediments and on the Blake Nose in the middle-upper Albian zones of $T$. primula- $T$. breggiensis.

\section{Reinholdella ultima Dailey}

(Plate 8, Figure 7)

Reinholdella ultima Dailey, 1970, Contrib. Cush. Found. Foram. Res., v. 21, p. 3 , p. 110 , pl. 14, fig. 5, 6. 
This smooth Reinholdella species was first described from the Budden Canyon Formation, California where it ranges from Aptian through Cenomanian (Dailey, 1970). Bartenstein and Bolli (1973, p. 415) state that Conorboides bulgaricus Bartenstein, Bettenstaedt, and Kovatcheva from the Barremian of Bulgary may be closely related. On the Blake Nose, $R$. ultima occurs in the middle-upper Albian zones of $T$, primula- $T$, breggiensis.

\section{REFERENCES}

Bartenstein, H., 1976a. Foraminiferal zonation of the Lower Cretaceous in northwest Germany and Trinidad, West Indies: N. Jb. Geol. Palaont. Mh., v. 3, p. 187-192.

1976b. Practical applicability of a zonation with benthonic foraminifera in the worldwide Lower Cretaceous: Geol. Mijnbouw, v. 55, p. 83-86.

Bartenstein, H. and Bolli, H.M., 1973. Die Foraminiferen der Unterkreide von Trinidad, W.I.-Maridale Formation (cotyplokalitat): Eclog. Geol. Helv., v. 66, p. 389-418.

Bartenstein, H., Bettenstaedt, F., and Bolli, H.M., 1957. Die Foraminiferen der Unterkreide von Trinidad, BWI-Cuche und Toco Formation: Eclog. Geol. Helv., v. 50, pt. 1, p. 565 .

1966. Die Foraminiferen der Unterkreide von Trinidad, W.I.-Maridale-Formation (Typlokalitat): Eclog. Geol. Helv., v. 59, pt. 1, p. 129-175.

Berthelin, M., 1880. Memoire sur les foraminiferes fossiles de l'étage Albien de Montcley (Doubs): Mem. Soc. Geol. France, v, 1, p. 1-75.

Bolli, H.M., 1959. Planktonic foraminifera from the Cretaceous of Trinidad, B.W.I.: Am. Paleontol. Bull., v. 39 , p. $257-273$

Chapman, F., 1866 (1970). The foraminifera of the Gault of Folkestone: J. Roy. Microsc. Soc., 1866. Repr. Antiq. Junk, Netherlands 1970 , p. 1-185.

Dailey, D.H., 1970. Some new Cretaceous foraminifera from the Budden Canyon Formation, northwestern Sacramento Valley, California: Cush. Found. Foram. Res., v. 21, p. 100111.

1973. Early Cretaceous foraminifera from the Budden Canyon Formation, northwestern Sacramento Valley, California: Univ. California Publ., Geol. Sci., v. 106 , p. $1-113$.

Dieni, I. and Massari, F., 1966. I Foraminiferi del Valanginiano superiore di Orosei (Sardegna): Palaeont. Ital., v. 61, p. 75-186.

Eicher, D.L. and Worstell, P., 1970. Cenomanian and Turonian foraminifera from the Great Plains, United States: Micropaleontology, v. 16, p. 269-324.

Frizzel, D.L., 1954. Handbook of Cretaceous foraminifera of Texas: Bur. Econ. Geol. Texas, Rept. 22, p. 1-231.

Grabert, B., 1959. Phylogenetische Untersuchungen an Gaudryina und Spiroplectinata (Foram.) besonders aus dem nordwestdeutschen Apt and Alb: Abh. Senckenb. Natur. Ges., v. 498, p. 71.

Gradstein, F.M., 1977. Biostratigraphy and biogeography of Jurassic Grand Banks foraminifera: Proc. 1st Int. Symp. Benth. Foram., Halifax, N.S., 1975, Maritime Sediments, Special Publication, no. 2, p. 557-583.

Gradstein, F.M., Williams, G.L., Jenkins, W.A.M., and Ascoli, P., 1975. Mesozoic and Cenozoic stratigraphy of the Atlantic continental margin, eastern Canada: Canadian Soc. Petrol. Geol. Mem. 4, p. 103-131.

Hermes, J.J., 1969. Late Albian foraminifera from the Subbetic of southern Spain: Geol. Mijnb., v. 48, p. 35-67.

Jannin, F., 1967. Les "Valvulineria" de l'Albien de L'Aube: Rev. Micropal., v. 10, p. 153-178.

Jenkins, W.A.M., Ascoli, P., Gradstein, F.M., Jansa, L.F., and Williams, G.L., 1974. Stratigraphy of the Amoco IOE
A-1 Puffin G-90 well, Grand Banks of Newfoundland: Geol. Surv. Canada Paper 74-61, p. 1-12.

Krasheninnikov, V.A., 1973. Cretaceous benthonic foraminifera, leg 20, Deep Sea Drilling Project. In Heezen, B.C., MacGregor, I.D., et al., Initial Reports of the Deep Sea Drilling Project, Volume 20; Washington (U.S. Government Printing Office), p. 205-221.

Kuhry, B., 1971. Lower Cretaceous planktonic foraminifera from the Miravetes, Argos and Represa Formations (S.E. Spain): Rev. Esp. Micropal., v. 3, p. 219-237.

Loeblich, A.R. and Tappan, H., 1949. Foraminifera from the Walnut Formation (Lower Cretaceous) of northern Texas and southern Oklahoma: J. Paleontol., v. 23, p. 245-266. 1961. Cretaceous planktonic foraminifera. Pt. I. Cenomanian: Micropaleontology, v. 7, p. 257-304.

1964. Sarcodina, chiefly "Thecamoebians" and Foraminifera. In Moore, R.C. (Ed.), Treatise on invertebrate paleontology: Prot. 2, pt. C. (Kansas Univ. Press).

Longoria, J.F., 1974. Stratigraphic, morphologic and taxonomic studies of Aptian planktonic foraminifera: Rev. Esp. Micropal., spec. vol. 1974, p. 1-109.

Luterbacher, H.P., 1972. Foraminifera from the Lower Cretaceous and Upper Jurassic of the northwestern Atlantic. In Hollister, C.D., Ewing, J.I., et al., Initial Reports of the Deep Sea Drilling Project, Volume 11: Washington (U.S. Government Printing Office), p. 561593.

1975. Early Cretaceous foraminifera from the northwestern Pacific: Leg 32 of the Deep Sea Drilling Project. In Larson, R.L., Moberly, R., et al., Initial Reports of the Deep Sea Drilling Project, Volume 32: Washington (U.S. Government Printing Office), p. 703718.

Malapris-Bizouard, M., 1967. Les Lingulogavelinelles de l'Albien inferieur et moyen de L'Aube: Rev. Micropal., v. 10, p. 128-150.

Marianos, A.W. and Zingula, R.P., 1966. Cretaceous planktonic foraminifers from Dry Creek, Tehama County, California: J. Paleontol., v. 40, p. 328-342.

Maync, W., 1973. Lower Cretaceous foraminiferal fauna from Gorringe Bank, eastern North Atlantic. In Ryan, W. B.F., Hsu, J.J., et al., Initial Reports of the Deep Sea Drilling Project, Volume 13: Washington (U.S. Government Printing Office), p. 1075-112.

Michael, E., 1966. Die Evolution der Gavelinelliden (foram.) in der N.W.-deutschen Unterkreide: Senckenb. Leth., v. 47, p. 411-459.

, 1967. Die Mikrofauna des N.W. deutschen Barreme, teil 1: Die Foraminiferen des N.W.-deutschen Barreme: Palaeontology, v. 12, p. 1-153.

Michael, F.Y., 1972. Planktonic foraminifera from the Comanchean Series (Cretaceous) of Texas: J. Foram. Res., v. 2 , p. $200-221$.

Moullade, M., 1966. Etude stratigraphique et micropaléontologique du Cretacé inferieur de la "Fosse Vocontienne": Doc. Labo. Geol. Fac. Sci Lyon, no. 15, fasc. 1,2 , p. 369 .

Ohm, U., 1967. Zur Kenntnis der Gattungen Reinholdella, Garantella und Epistomina (foramin.): Palaeontology, v. 127 A, p. $85-188$

Pazdro, O., 1969. Middle Jurassic Epistominidae (foraminifera) of Poland: Studia Geol., Polonica, v. 27, p. $1-92$.

Pessagno, E.A., Jr., 1967. Upper Cretaceous planktonic foraminifera from the Western Gulf Coastal Plain: Palaeont. Am., v. 5, p. 1-387.

Saito, T., Burckle, L.H., and Hays, J.D., 1974. Implications of some pre-Quaternary sediment cores and dredgings. In 
F. M. GRADSTEIN

Hay, W.W. (Ed.), Studies in paleo-oceanography: Soc. Econ. Paleont. Mineral., Spec. Publ. 20, p. 6-36.

Scheibnerova, V., 1971. Lingulogavelinella (foraminifera) in the Cretaceous of the Great Artesian Basin, Australia: Micropaleontology, v. 17, p. 109-116.

1974. Aptian-Albian benthonic foraminifera from DSDP leg 27, sites 259, 260 and 263, eastern Indian Ocean. In Veevers, J.J., Heirtzler, J.R., et al., Initial Reports of the Deep Sea Drilling Project, Volume 27: Washington (U.S. Government Printing Office), p. 697-741.

Sheridan, R.E. and Osburn, W.L., 1975. Marine geological and geophysical studies of the Florida-Blake PlateauBahamas area: Canadian Soc. Petrol. Geol. Mem. 4, p. 933.

Sigal, J., 1952. Aperçu stratigraphique sur la micro-paèltacèe: XIX Int. Geol. Congr., Monogr. Reg. première sèrie: Algerie, no. 26, p. 1-47.

1965. Etat des connaissances sur les foraminiferes du Crètacè inferieur. In Colloque sur le Cretacèce inferieur Lyon, Sept. 1963: Mem. Bur. Rech. Geol. Min., no. 34, p. $489-502$.
1966. Contribution à une monographie des Rosalines I. Le genre Ticinella Reichel, souche des Rotalipores: Eclog. Geol. Helv., v. 59, p. 185-218.

Simon, W. and Bartenstein, H. (Ed.), 1962. Leitfossilien der Micropalaontologie: Berlin (Gebr. Bornstraeger).

Subbotina, N.N., 1953 (1971). Fossil foraminifera of the USSR, Globigerinidae, Hantkeninidae and Globorotaliidae (transl. from Russian): Collet's Publs. Ltd., 1971.

Tappan, H., 1940. Foraminifera from the Grayson Formation of northern Texas: J. Paleontol., v. 14, p. 93126.

1943. Foraminifera from the Duck Creek Formation of Oklahoma and Texas: J. Paleontol., v. 17, p. 476-517.

Ten Dam, A., 1950. Les foraminiferes de l'Albien des PaysBas: Mem. Soc. Geol. France, no. 63, p. 1-65.

van Hinte, J.E., 1976. A Cretaceous time scale: Am. Assoc. Petrol. Geol. Bull., v. 60, p. 498-516.

678 



\section{PLATE 1}

Hole 391C

Figure 1

Figure 2

Figure 3

Figure 4

Figure 5

Figure 6

Figure 7

Figure 8

Figure 9

Figure 10

Figure 11

Figure 12

Figure 13

Figure 14

Figure 15

Figure 16
Plectorecurvoides sp.; 391C-5, CC; Plectorecurvoides assemblage. The biserial coil is vaguely visible in the last chamber pair. $\times 150$.

Plectorecurvoides sp; 391C-5, CC; Plectorecurvoides assemblage. $\times 150$.

Trochammina sp.; 391C-8, CC; Plectorecurvoides assemblage. $\times 112$.

Trochammina globigeriniformis (Parker and Jones) $391 \mathrm{C}-8, \mathrm{CC}$; Plectorecurvoides assemblage. $\times 200$.

Bolivinopsis sp.; 391C-5, CC; Plectorecurvoides assemblage. $\times 250$.

Glomospira sp.; 391C-6, CC; Plectorecurvoides assemblage. $\times 145$.

Uvigerammina sp.; 391C-5, CC; Plectorecurvoides assemblage. $\times 200$.

Glomospirella sp.; 391C-6, CC; Plectorecurvoides assemblage. $\times 100$.

Gavelinella intermedia (Berthelin); 390A-14, CC; $66-68 \mathrm{~cm}$; G. barremiana-L. sigali Zone. $\times 225$.

Gavelinella barremiana Bettenstaedt; 391C-14-3, $66-68 \mathrm{~cm}$; G. barremiana-L. sigali Zone. $\times 250$.

Hedbergella sigali Moullade; 391C-14-3, 66-68 cm; G. barremiana-L. sigali Zone. $\times 350$.

Lenticulina crepidularis (Roemer); 391C-14-3, 66$68 \mathrm{~cm} ; G$. barremiana-L. sigali Zone. $\times 250$.

Dorothia praehauteriviana Dieni and Massari (small triserial stage only); 391C-26-3, 60-62 cm; Dorothia praehauteriviana assemblage. $\times 250$.

Dorothia praehauteriviana Dieni and Massari; $391 \mathrm{C}-26-3,60-62 \mathrm{~cm}$; Dorothia praehauteriviana assemblage. $\times 70$.

Conorboides hofkeri (Bartenstein and Brand); 391C-26-3, 60-62 cm; Dorothia praehauteriviana assemblage (pseudo-arenaceous appearance due to pyritization of test). $\times 300$.

Lenticulina ex gr. nodosa (Reuss); 391C-26-3, 60-62 $\mathrm{cm}$; Dorothia praehauteriviana assemblage. $\times 60$. 

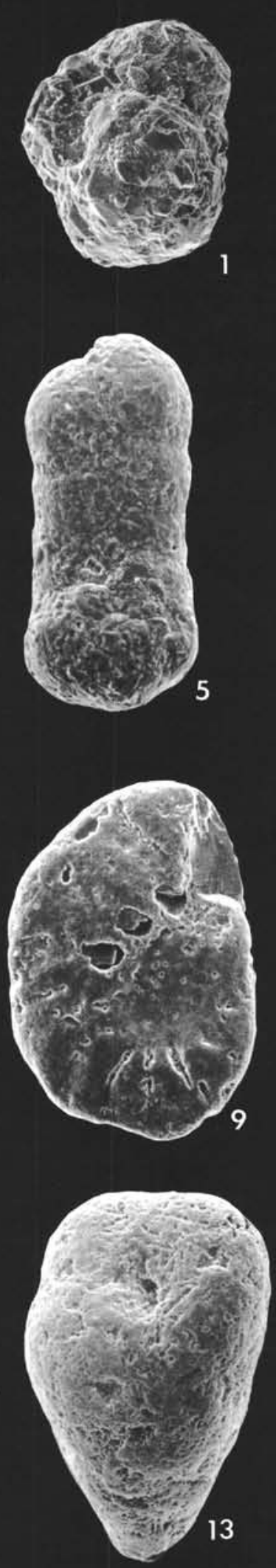
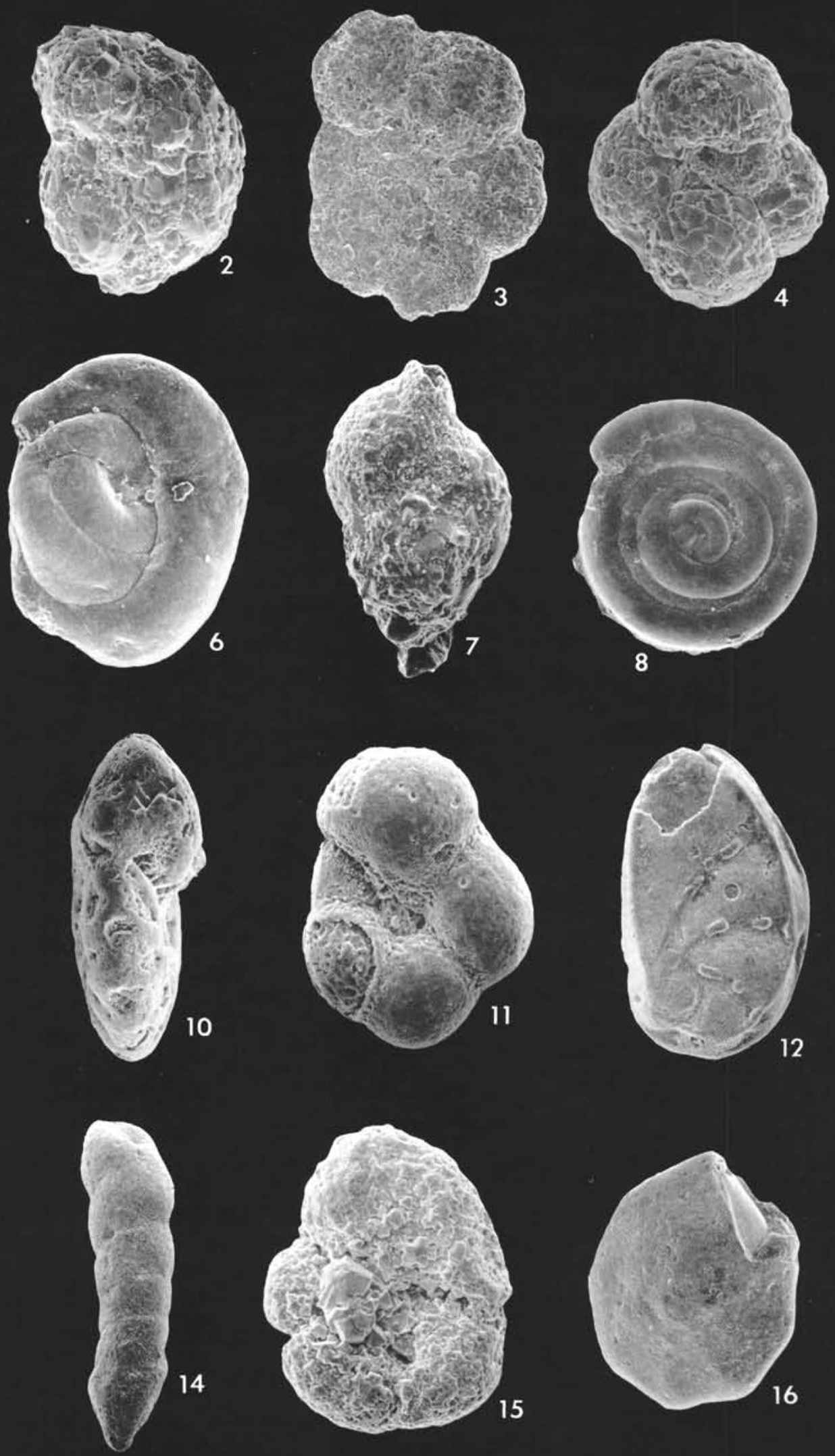
PLATE 2

Group of Gaudryina dividens Grabert at Sites 390, 392

Figure 1

Figure 2

Figure 3

Figure 4

Figure 5

Figure 6

Figure 7

Figure 8

Figure 9

Figure 10

Figure 11

Figure 12

Figure 13

Figure 14

Figure 15

Figure 16

Figure 17

Figure 18
Spiroplectinata lata Grabert; 390-5-1, $87-89$ cm; Globigerinelloides algerianus Zone. $\times 70$.

Spiroplectinata lata Grabert; 390-5-1; $87-89$ cm; Globigerinelloides algerianus Zone. $\times 67$.

Carbonate particles, including nannofossils, are the building material of Spiroplectinata lata Grabert and other taxa in the group of Gaudryina dividens Grabert (detail of Figure 2). $\times 625$.

Spiroplectinata lata Grabert; 392A-3-3, 50-52 cm; Globigerinelloides algerianus Zone. $\times 80$.

Spiroplectinata lata Grabert; 392A-3-1, $46-48 \mathrm{~cm}$; Ticinella primula Zone. $\times 130$.

Spiroplectinata lata Grabert; 392A-3, CC; (?Schackoina cabri-) Globigerinelloides algerianus Zone. $\times 60$.

Spiroplectinata lata Grabert; 392A-3-3, $50-52 \mathrm{~cm}$; Globigerinoides algerianus Zone. $\times 50$.

Spiroplectinata lata Grabert; 392A-3-3, 50-52 cm; Globigerinelloides algerianus Zone. $\times 57$.

Gaudryina dividens Grabert; 390A-14-5, 119-121 cm; Ticinella primula Zone. $\times 185$.

Gaudryina dividens Grabert; 390-3-3, 80-82 cm; Ticinella primula Zone. $\times 55$.

Gaudryina dividens Grabert; 390-3-3, 80-82 cm; Ticinella primula Zone. $\times 55$.

Gaudryina dividens Grabert var. compacta Grabert; 390-3-3, 80-82 cm; Ticinella primula Zone. $\times 55$.

Gaudryina dividens Grabert var. compacta Grabert; 390-3-3, 80-82 cm; Ticinella primula Zone $\times 55$.

Gaudryina dividens Grabert var. reicheli Bartenstein, Bettenstaedt and Bolli; 390-5-1, 87-89 cm; Globigerinelloides algerianus Zone. $\times 80$.

Gaudryina dividens Grabert var. reicheli Bartenstein, Bettenstaedt and Bolli; 392A-3, CC; (?Schackoina cabri-) Globigerinelloides algerianus Zone. $\times 60$.

Gaudryina dividens Grabert; 392A-3-1, 46-48 cm; Ticinella primula Zone. $\times 110$.

Gaudryina dividens Grabert; 390A-14-5, 119-121 cm; Ticinella primula Zone. $\times 50$.

Gaudryina dividens Grabert; 392A-3-1, $46-48 \mathrm{~cm}$; Ticinella primula Zone. $\times 60$. 


\section{PLATE 2}
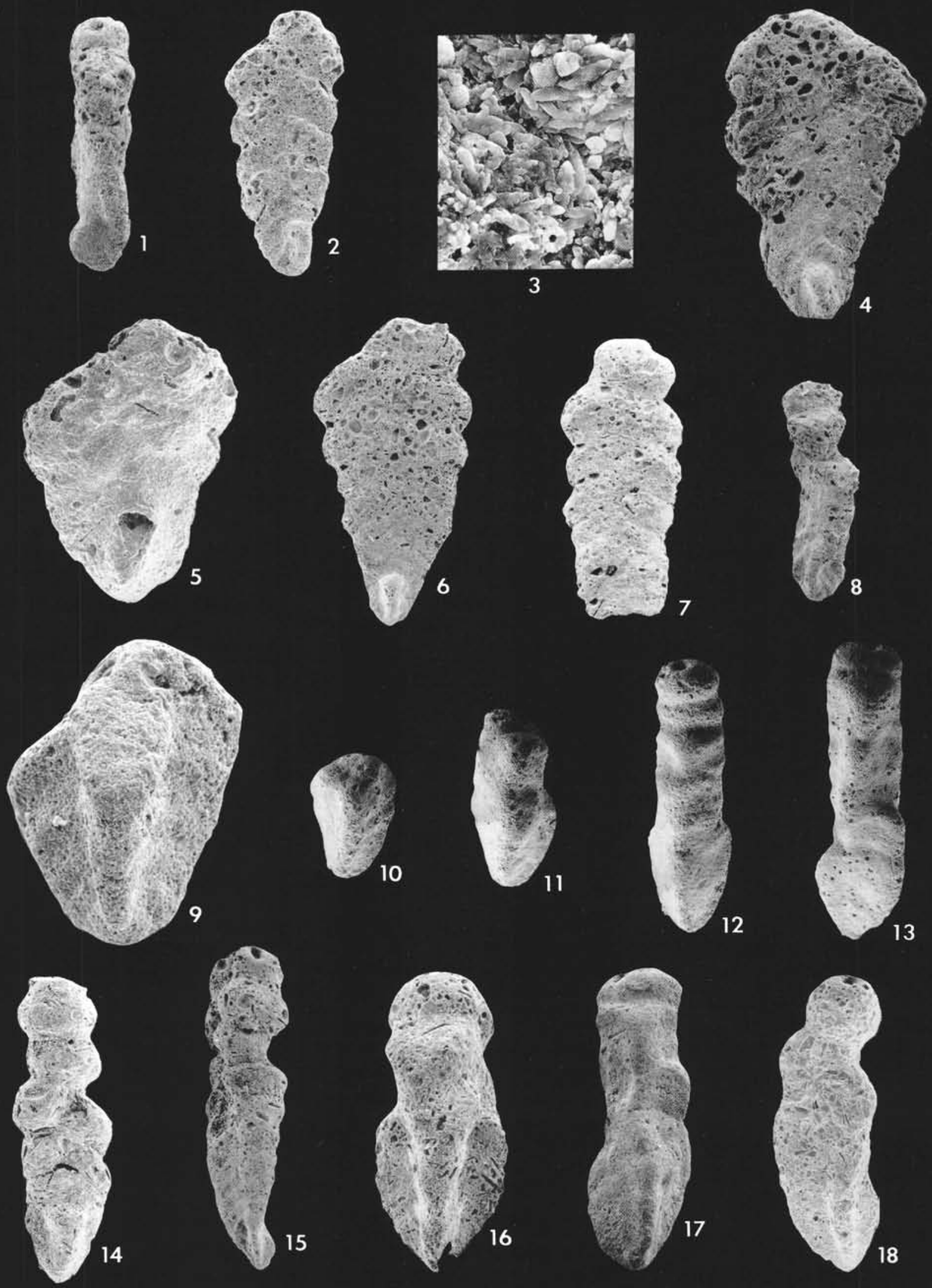


\section{PLATE 3}

Sites 390,392

Figure 1

Figure 2

Figure 3

Figure 4

Figure 5

Figure 6

Figures 7, 8

Figure 9

Figure 10

Figure 11

Figure 12

Figure 13

Figure 14

Figure 15

Figure 16

Figure 17
Orthokarstenia shastaensis Dailey; 392A-2-1, 84-86 $\mathrm{cm}$; Ticinella breggiensis Zone. $\times 110$.

Orthokarstenia shastaensis Dailey; 392A-2-1, 84-86 $\mathrm{cm}$; Ticinella breggiensis Zone. $\times 110$.

Orthokarstenia shastaensis Dailey; 392A-2-1, 84-86 $\mathrm{cm}$; Ticinella breggiensis Zone. $\times 110$.

Orthokarstenia shastaensis Dailey, a detail of aperture in earlier chamber; 392A-2-1, 84-86 cm; Ticinella breggiensis Zone. $\times 325$.

Pleurostomella obtusa Berthelin; 390-3-3, 80-82 $\mathrm{cm}$; Ticinella primula Zone. $\times 100$.

Pleurostomella obtusa Berthelin; 390-3-3, 80-82 $\mathrm{cm}$; Ticinella primula Zone. $\times 100$.

Pleurostomella obtusa Berthelin; 390-3-3, 80-82 $\mathrm{cm}$; Ticinella primula Zone. $\times 50$. (Figure 7; details of aperture of specimen in Figure 8. $\times 250$.)

Dentalina debilis (Berthelin); 392A-2-1, 84-86 cm; Ticinella breggiensis Zone. $\times 60$.

Tristix excavatus (Reuss); 390-3-3, 80-82 cm; Ticinella primula Zone. $\times 65$.

Pleurostomella obtusa Berthelin; 390-3-3, 80-82 $\mathrm{cm}$; Ticinella primula Zone. $\times 220$.

Dorothia trochus (d'Orbigny); 392A-2-1, $84-86 \mathrm{~cm}$; Ticinella breggiensis Zone. $\times 100$.

Dorothia sp.; 390-3-3, 80-82 cm; Ticinella primula Zone. $\times 90$.

Dorothia gradata (Berthelin); 390-5-1, $87-89 \mathrm{~cm}$; Globigerinelloides algerianus Zone. $\times 65$.

Dorothia gradata (Berthelin); 390-5-1, 87-89 cm; Globigerinelloides algerianus Zone. $\times 65$.

Dorothia gradata (Berthelin); 390-5-1, $87-89 \mathrm{~cm}$; Globigerinelloides algerianus Zone. $\times 65$.

Dorothia gradata (Berthelin); 390-5-1, $87-89 \mathrm{~cm}$; Globigerinelloides algerianus Zone. $\times 65$. 
PLATE 3
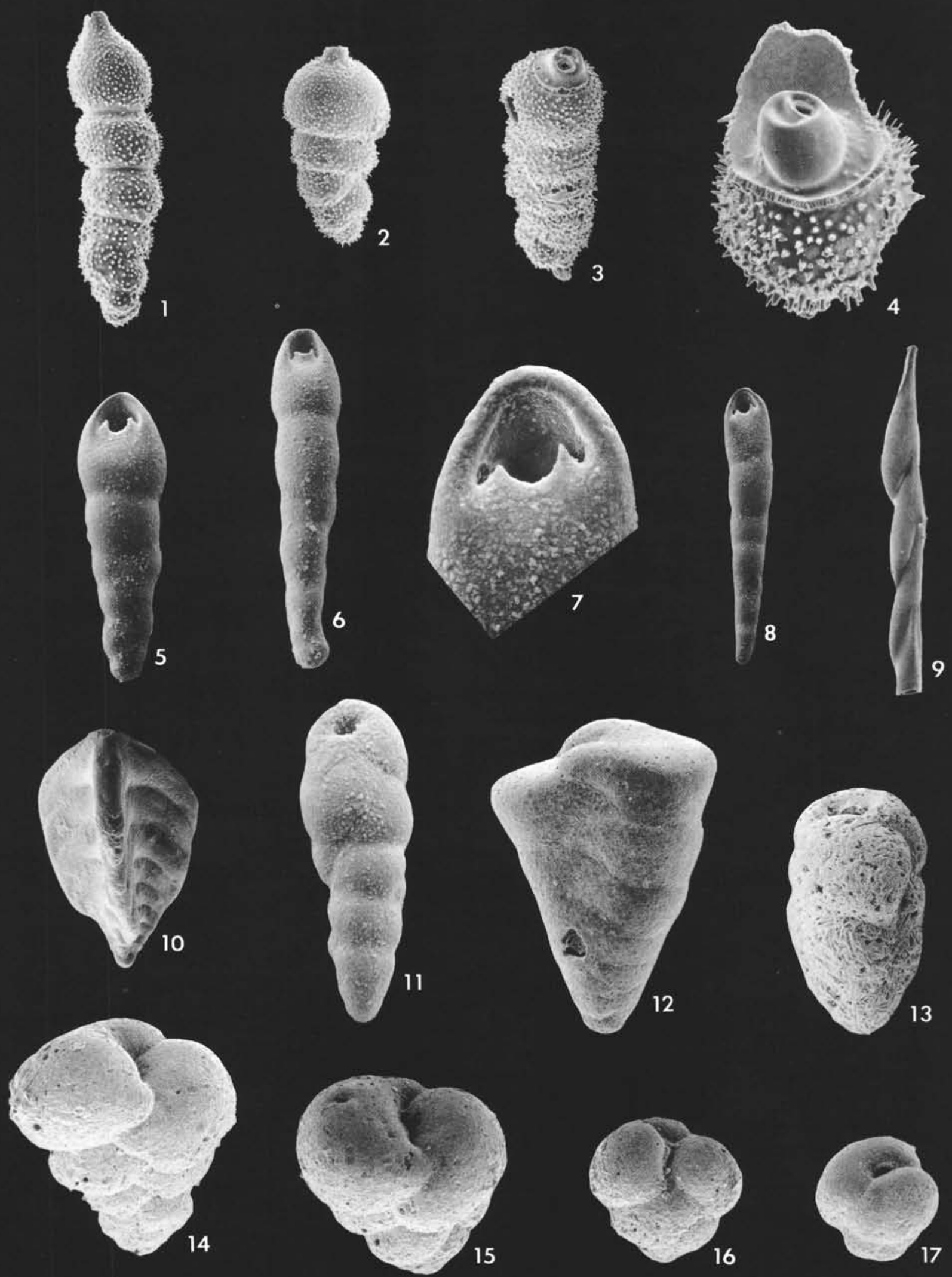


\section{PLATE 4}

Sites 390,392

Figure 1

Figure 2

Figure 3

Figure 4

Figure 5

Figure 6

Figure 8

Figure 9

Figure 10

Figure 11
Lenticulina vocontiana Moullade; 392A-3-3, 50-52 $\mathrm{cm}$; Globigerinelloides algerianus Zone. $\times 90$.

Lenticulina meridiana Bartenstein, Bettenstaedt, and Kovatcheva; 392A-4-1, 110-112 cm; Gavelinella barremiana-Lenticulina $(M$.) sigali Zone. $\times 55$.

Lenticulina turgidula (Reuss); 390-3-3, $80-82 \mathrm{~cm}$; Ticinella primula Zone. $\times 75$.

Lenticulina ex. gr. ouachensis (Sigal); 392A-4-1, $110-112 \mathrm{~cm}$; Gavelinella barremiana-Lenticulina (M.) sigali Zone. $\times 87$.

Lenticulina (Marginulopsis) sigali Bartenstein, Bettenstaedt, and Bolli; 390-6, CC, Gavelinella barremiana-Lenticulina (M.) sigali Zone. $\times 100$.

Lenticulina (Marginulopsis) sigali Bartenstein, Bettenstaedt, and Bolli; 392A-4-1, 110-112 cm; Gavelinella barremiana-Lenticulina (M.) sigali Zone. $\times 100$.

Lenticulina (Marginulopsis) sigali Bartenstein, Bettenstaedt, and Bolli; 392A-4, CC; Gavelinella barremiana-Lenticulina $(M$.) sigali Zone. $\times 100$.

Lenticulina ex. gr. ouachensis Sigal; 392A-4-1, 110$112 \mathrm{~cm}$; Gavelinella barremiana-Lenticulina (M.) sigali Zone. $\times 55$.

Lenticulina crepidularis (Roemer); 390-6, CC; Gavelinellina barremiana-Lenticulina (M.) sigali Zone. $\times 80$.

Lenticulina ex. gr. nodosa (Reuss); 392A-4, CC; Gavelinella barremiana-Lenticulina (M.) sigali Zone. $\times 80$.

Epistomina ornata (Roemer); 390-6, CC; Gavelinella barremiana-Lenticulina (M.) sigali Zone. $\times 80$. 


\section{PLATE 4}
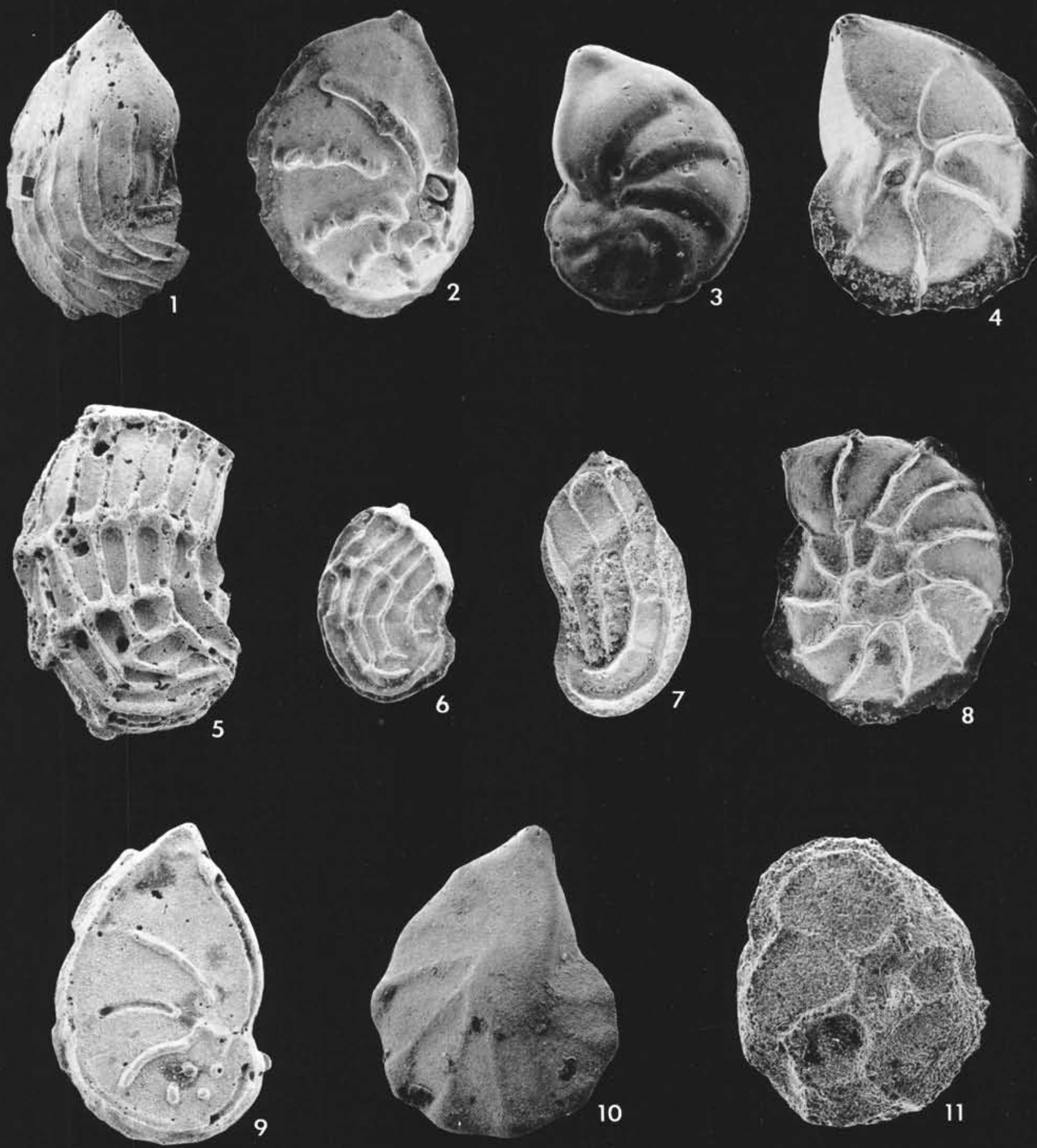


\section{PLATE 5}

Gavelinellids at Sites 390, 392

Figure $1 \quad$ Gavelinella sp. A (spiral view); 390-5-2, 60-62 cm; Globigerinelloides algerianus Zone. $\times 90$.

Figures 2, 3 Gavelinella sp. A; 390-5-2, 60-62 cm; Globigerinelloides algerianus Zone. $\times 90$.

Figure 4 Tongue-like flaps which cover the umbilicus in an imbricate manner in Gavelinella sp. A. Detail of Figure 3. $\times 350$.

Figure 5 Gavelinella sp. A (small, concavo-convex; reminiscent of $G$. barremiana Bettenstaedt); 392A2-3, 104-106 cm; Ticinella breggiensis Zone. $\times 157$.

Figures 6,7 Gavelinella sp. A; 392A-2-3, 104-106 cm; Ticinella breggiensis Zone. $\times 135$.

Figure $8 \quad$ Gavelinella $\mathrm{sp}$. B (?Orithostella); 390-5-1, 87-89 cm; Globigerinelloides algerianus Zone. $\times 110$.

Figure 9 Tongue-like flaps which form an imbricate umbilical cover in Lingulogavelinella ciryi Malapris-Bizouard. Detail of Figure 13. $\times 500$.

Figures 10,11 Gavelinella sp. A (transitional to G. intermedia Berthelin); 392A-2-3, 104-106 cm; Ticinella breggiensis Zone. $\times 100$.

Figure 12 Gavelinella sp. A (spiral view); 392A-2-3, 104-106 $\mathrm{cm}$; Ticinella breggiensis Zone. $\times 100$.

Figures 13, 14 Lingulogavelinella ciryi Malapris-Bizouard; 392A2-2, 146-148 cm; Ticinella breggiensis Zone. $\times 115$.

Figure 15 Lingulogavelinella ciryi Malapris-Bizouard (note crenulate sutures and vague umbilical flaps); 392A-2-2, 146-148 cm; Ticinella breggiensis Zone. $\times 150$.

Figures 16, 17 Lingulogavelinella ciryi Malapris-Bizouard; 390-3$3,80-82 \mathrm{~cm}$; Ticinella primula Zone. $\times 115$. 
PLATE 5
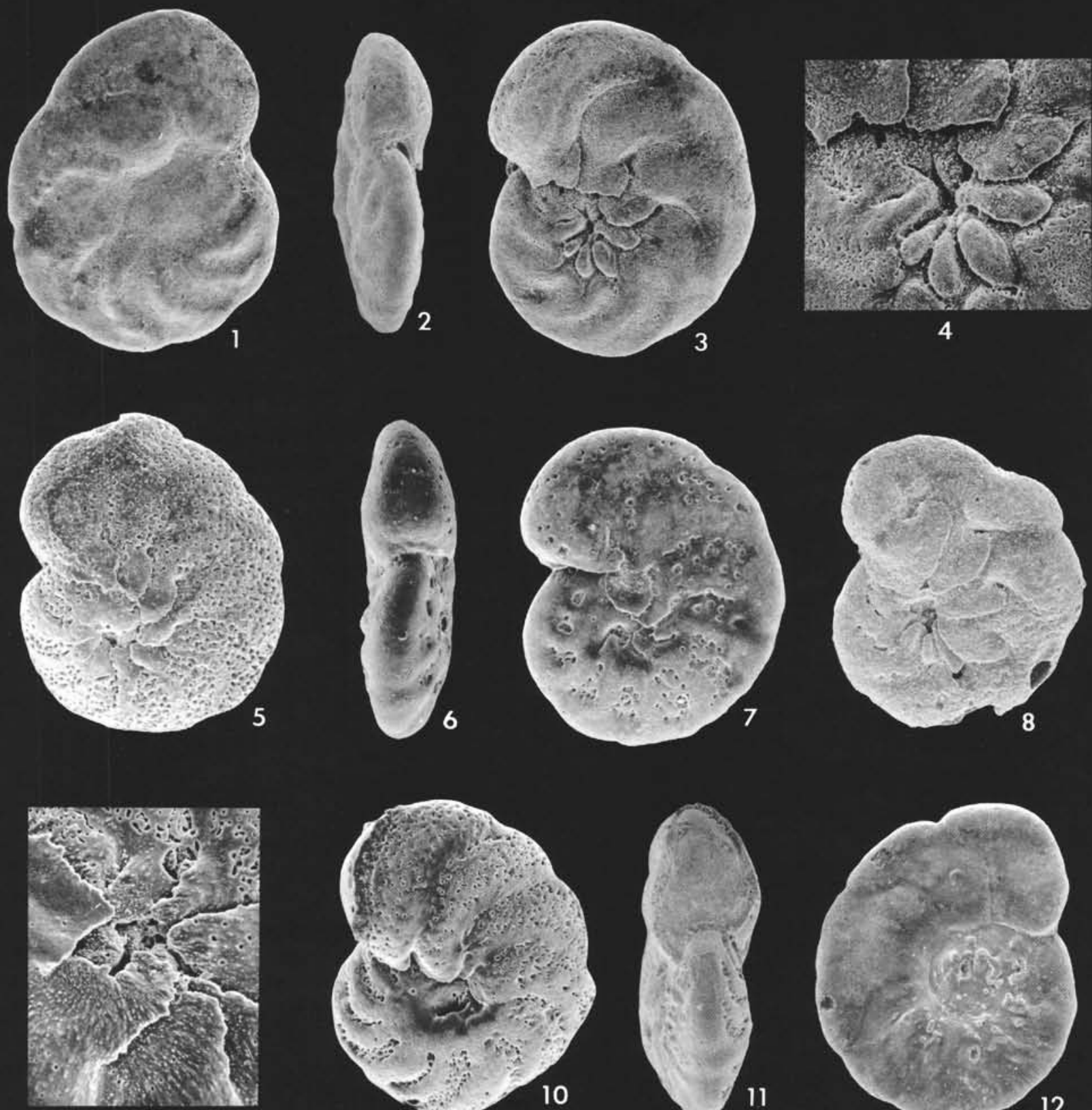

9
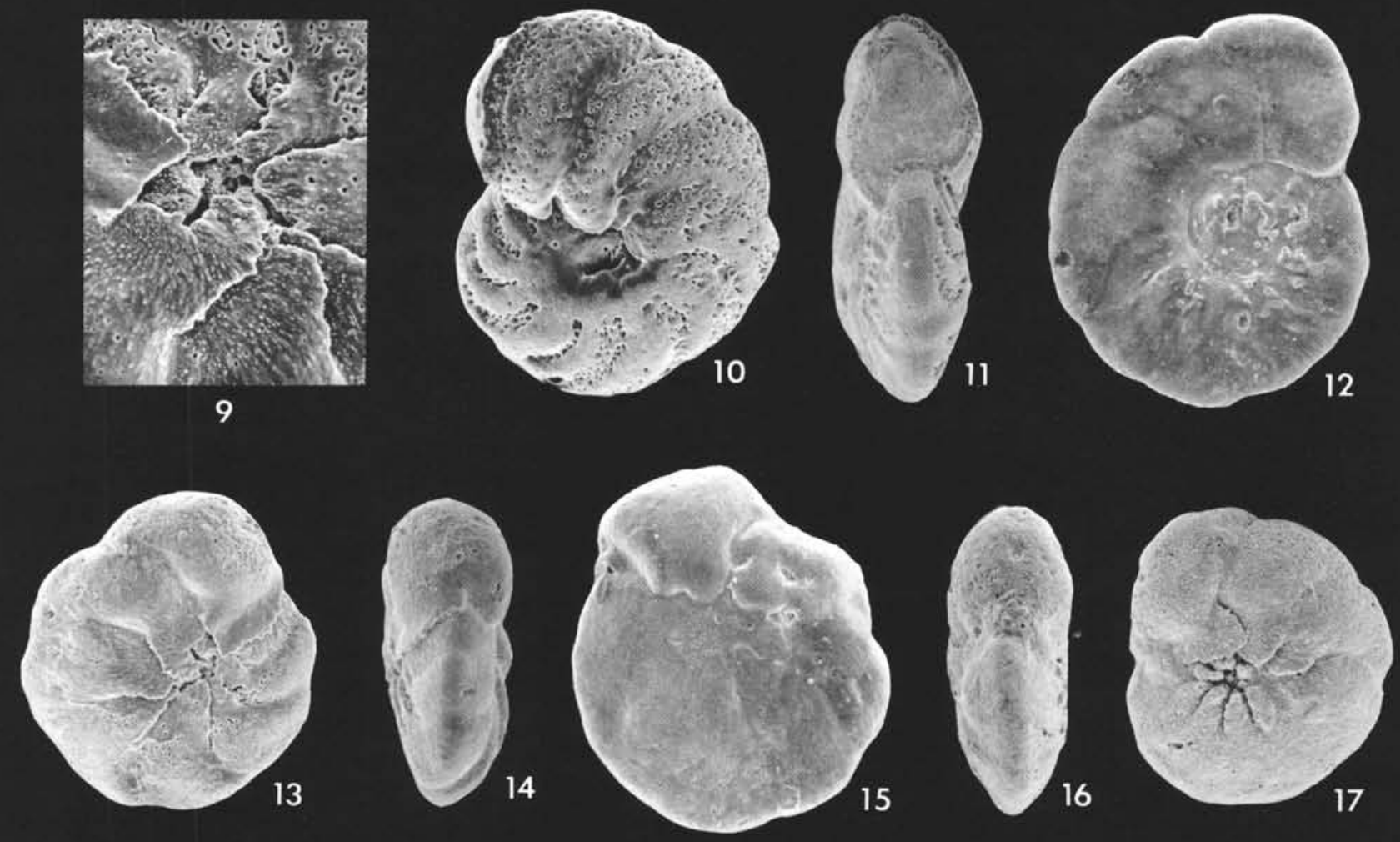


\section{PLATE 6}

Gavelinellids at Sites 390, 392

Figures 1,2 Gavelinella intermedia (Berthelin)-Gavelinella ammonoides (Reuss); 390-3, CC; Ticinella primula Zone. $\times 120$.

Figure 3 Gavelinella intermedia (Berthelin)-Gavelinella ammonoides (Reuss); 392A-3, CC; (?Schackoina cabri-) Globigerinelloides algerianus Zone. $\times 130$.

Figure $4 \quad$ Gavelinella intermedia (Berthelin)-Gavelinella ammonoides (Reuss); 392A-3, CC; (?Schackoina cabri-) Globigerinelloides algerianus Zone. $\times 150$.

Figures 5, 6 Gavelinella intermedia (Berthelin); 390-5-1, 87-89 $\mathrm{cm}$; Globigerinelloides algerianus Zone. $\times 90$.

Figure $7 \quad$ Gavelinella intermedia (Berthelin); 390A-14, CC; Ticinella primula Zone. $\times 135$.

Figure $8 \quad$ Gavelinella intermedia (Berthelin); 390A-14-5, 119$121 \mathrm{~cm}$; Ticinella primula Zone. $\times 112$.

Figures 9, 10 Gavelinella intermedia (Berthelin); 392A-3, CC; (?Schackoina cabri-) Globigerinelloides algerianus Zone. $\times 135$.

Figures 11, 12 Gavelinella intermedia (Berthelin); 390-3-3, 80-82 $\mathrm{cm}$; Ticinella primula Zone. $\times 75$.

Figure $13 \quad$ Gavelinella intermedia (Berthelin); 390-5-1, 87-89 $\mathrm{cm}$; Globigerinelloides algerianus Zone. $\times 110$.

Figure 14 Gavelinella barremiana (Bettenstaedt) (Note the flap on the last chamber reaching over the umbilicus.); 392A-4, CC; Gavelinella barremianaLenticulina $(M$.) sigali Zone. $\times 235$.

Figure $15 \quad$ Gavelinella barremiana (Bettenstaedt) (spiral view); 390-5, CC; Globigerinelloides blowi Zone. $\times 260$.

Figures 16,17 Gavelinella barremiana (Bettenstaedt); 390-5, CC; Globigerinelloides blowi Zone. $\times 260$. 

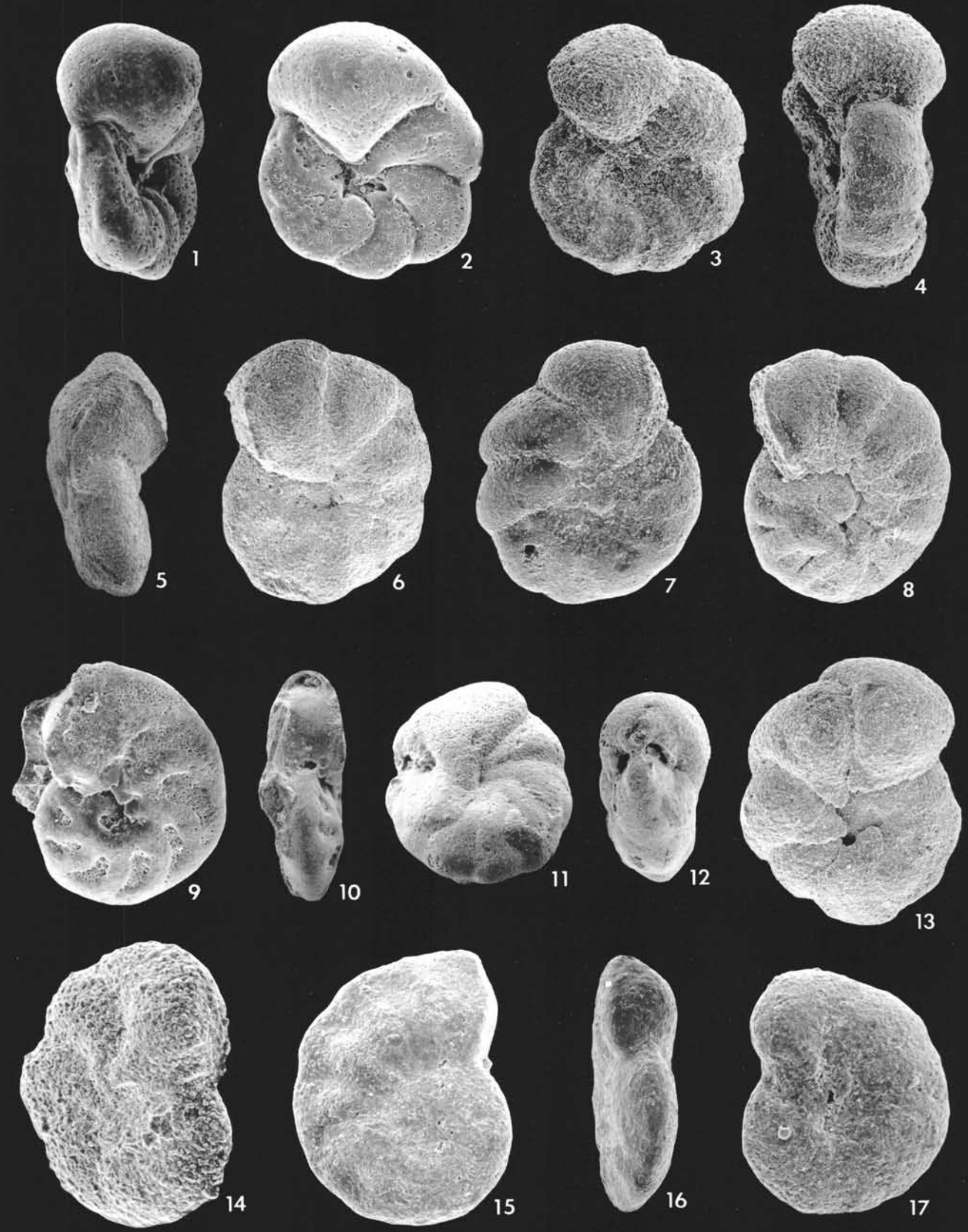


\section{PLATE 7}

Sites 390,392

Figures 1, 2 Osangularia insigna Dailey; 392A-2-1, 84-86 cm; Ticinella breggiensis Zone. $\times 125$.

Figure 3 Osangularia insigna Dailey; 392A-2-3, 104-106 cm; Ticinella breggiensis Zone. $\times 195$.

Figure 4 Osangularia insigna Dailey; 392A-2-3, 104-106 cm; Ticinella breggiensis Zone. $\times 130$.

Figures 5, 6 Osangularia utaturensis (Sastri and Sastry); 390-3$3,80-82 \mathrm{~cm}$; Ticinella primula Zone. $\times 100$.

Figures 7, 8 Osangularia utaturensis (Sastri and Sastry); 390-33, 80-82 cm; Ticinella primula Zone. $\times 90$.

Figure 9 Osangularia utaturensis (Sastri and Sastry); 390-42, 75-77 cm; Ticinella primula Zone. $\times 100$.

Figures 10, 11 Osangularia utaturensis (Sastri and Sastry); 390-42, 75-77 cm; Ticinella primula Zone. $\times 112$.

Figure 12 Osangularia utaturensis (Sastri and Sastry); 390-3$3,80-82 \mathrm{~cm}$; Ticinella primula Zone. $\times 112$.

Figure 13 Gavelinella intermedia (Berthelin); 390A-14-5, 119$121 \mathrm{~cm}$; Ticinella primula Zone. $\times 110$.

Figure 14 Gavelinella $\mathrm{sp}$. C; $392 \mathrm{~A}-3-1,46-48 \mathrm{~cm}$; Ticinella primula Zone. $\times 92$.

Figures 15, 16 Gavelinella $\mathrm{sp}$. C; 392A-3-1, $46-48 \mathrm{~cm}$; Ticinella primula Zone. $\times 92$. 


\section{PLATE 7}
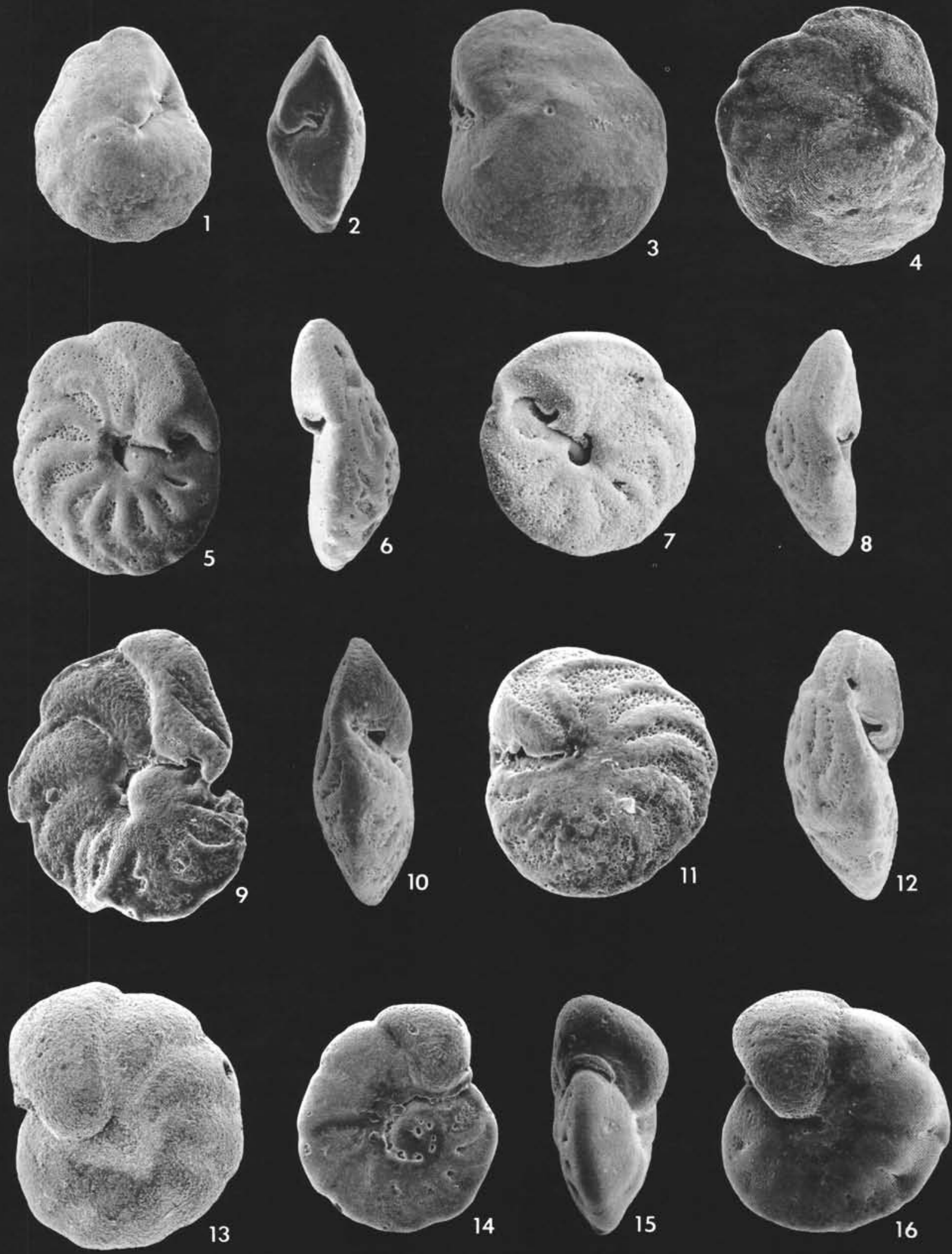


\section{PLATE 8}

Sites 390,392

Figure $1 \quad$ Epistomina ex. gr. spinulifera (Reuss); 392A-2-1, $84-86 \mathrm{~cm}$; Ticinella breggiensis Zone. $\times 67$.

Figure 2 Epistomina ex. gr. spinulifera (Reuss); 392A-2-1, $84-86 \mathrm{~cm}$; Ticinella breggiensis Zone. $\times 27$.

Figure 3 Epistomina cretosa Ten Dam (spiral view); 392A2-1, 84-86 cm; Ticinella breggiensis Zone. $\times 95$.

Figure 4 Epistomina cretosa Ten Dam (umbilical view); 392A-2-1, 84-86 cm; Ticinella breggiensis Zone. $\times 95$.

Figure 5 Epistomina chapmani Ten Dam; 392A-2-1, 84-86 $\mathrm{cm}$; Ticinella breggiensis Zone. $\times 85$.

Figure 6 Ceratolamarckina sp.; 392A-3-1, 46-48 cm; Ticinella primula Zone. $\times 160$.

Figure 7 Reinholdella ultima Dailey (umbilical view); 392A2-1, 84-86 cm; Ticinella breggiensis Zone. $\times 87$.

Figure $8 \quad$ Reinholdella ultima Dailey (spiral view); 392A-2-1, $84-86 \mathrm{~cm}$; Ticinella breggiensis Zone. $\times 87$.

Figures 9, 10 Gyroidinoides primitiva Hofker; 390-3-3, 80-82 cm; Ticinella primula Zone. $\times 150$.

Figure $11 \quad$ Valvulineria gracillima Ten Dam; 390-3-3, 80-82 $\mathrm{cm}$; Ticinella primula Zone. $\times 140$.

Figure 12 Valvulineria gracillima Ten Dam; 390-3-3, 80-82 $\mathrm{cm}$; Ticinella primula Zone. $\times 200$.

Figure 13 Conorotalites aptiensis (Bettenstaedt); 392A-4-1, $110-112 \mathrm{~cm}$; $G$. barremiana-L. sigali Zone. $\times 115$

Figures 14, 15 Conorotalites aptiensis (Bettenstaedt); 390-3-3, 80$82 \mathrm{~cm}$; Ticinella primula Zone. $\times 160$.

Figures 16, 17 Conorotalites aptiensis (Bettenstaedt); 392A-4-1, $110-112 \mathrm{~cm}$; G. barremiana-L. sigali Zone. $\times 200$. 


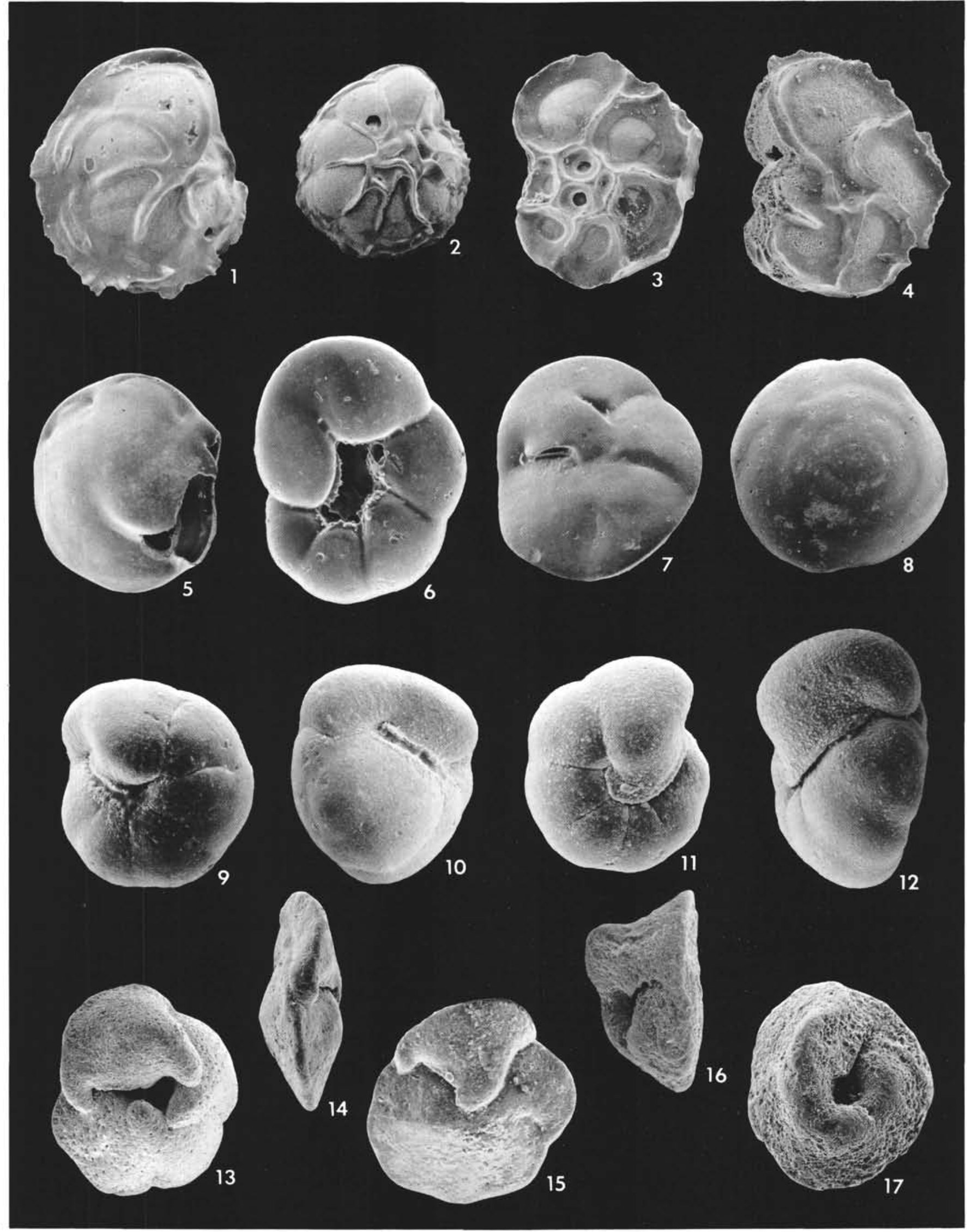




\section{PLATE 9}

Sites 390,392

Figure 1

Figure 2

Figures 3,4

Figure 5

Figure 6

Figure 7

Figure 8

Figures 9, 10

Figures 11, 12

Figure 13

Figure 14

Figure 15

Figure 16

Figure 17
Globigerinelloides ferreolensis (Moullade); 390-5-1, $87-89 \mathrm{~cm}$; G. algerianus Zone. $\times 195$.

Globigerinelloides ferreolensis (Moullade); 390-5-1, $87-89 \mathrm{~cm} ;$ G. algerianus Zone. $\times 195$.

Detail of wall of $G$. ferreolensis (Moullade) in Plate 10, Figure 15, showing coating of test with carbonate particles, including nannoconid (enlarged in Figure 4) and other nannofossils. Respectively, $\times 500$ and $\times 2250$.

Globigerinelloides blowi (Bolli); 390-5, CC; G. blowi Zone. $\times 375$.

Globigerinelloides blowi (Bolli); 390-5, CC; G. blowi Zone. $\times 275$.

Globigerinelloides blowi (Bolli); 390-5, CC; G. blowi Zone. $\times 250$.

Globigerinelloides blowi (Bolli); 390-5, CC; G. blowi Zone. $\times 250$.

"Globigerina" hoterivica Subbotina; 390-6-1; Gavelinella barremiana-Lenticulina $(M$.) sigali Zone. Respectively, $\times 155$ and $\times 135$.

"Globigerina" hoterivica Subbotina; 390-6, CC; Gavelinella barremiana-Lenticulina (M.) sigali Zone. $\times 175$.

"Globigerina" hoterivica Subbotina; 390-6, CC; Gavelinella barremiana-Lenticulina $(M$.$) sigali$ Zone. $\times 175$.

"Globigerina" hoterivica Subbotina; 390-6, CC; Gavelinella barremiana-Lenticulina (M.) sigali Zone. $\times 175$.

"Globigerina" hoterivica Subbotina; 390-6, CC; Gavelinella barremiana-Lenticulina (M.) sigali Zone. $\times 175$.

Praebulimina nannina (Tappan); 390-5, CC; Globigerinelloides blowi Zone. $\times 375$.

Praebulimina nannina (Tappan); 390-5, CC; Globigerinelloides blowi Zone. $\times 375$. 
PLATE 9

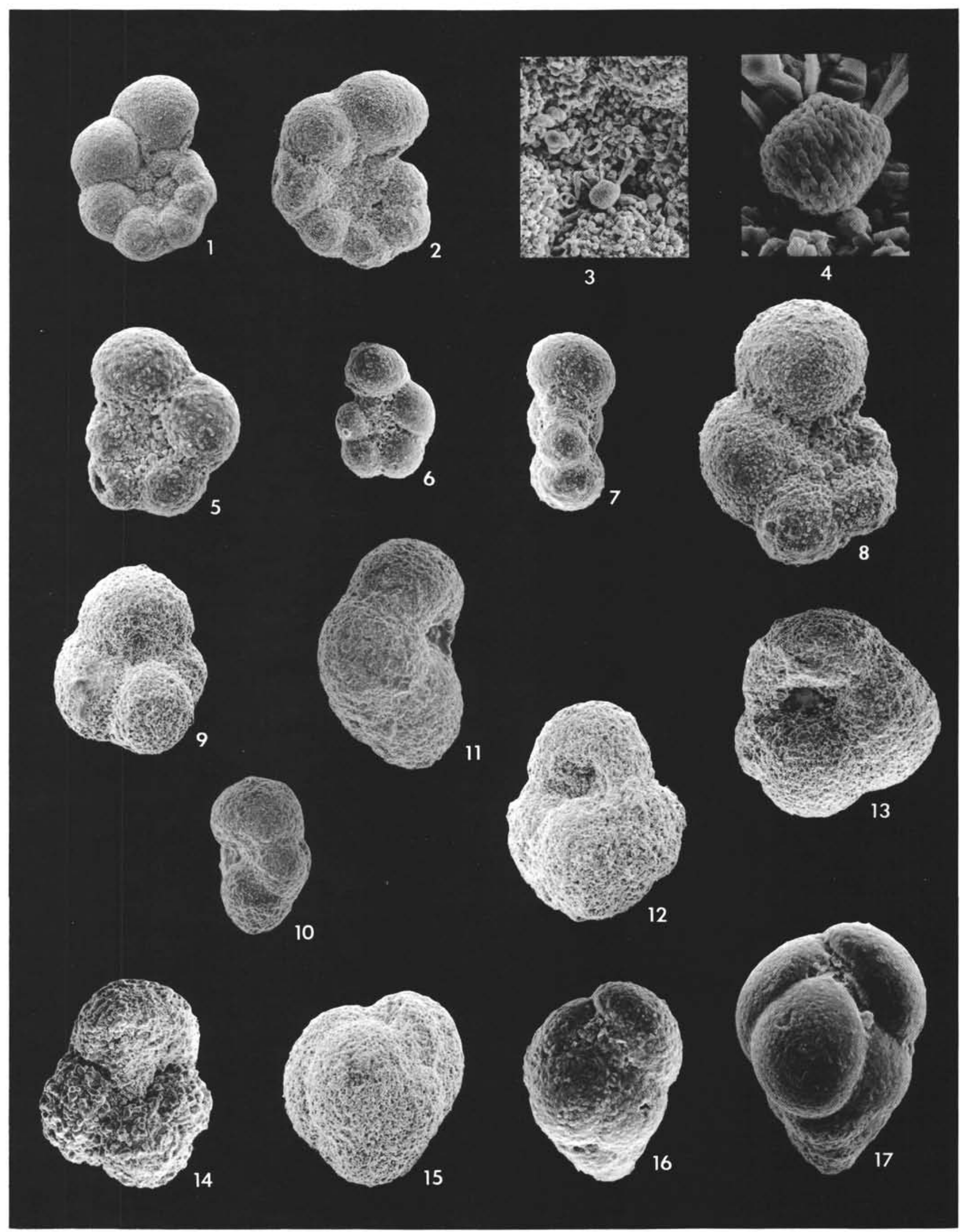




\section{PLATE 10}

Sites 390, 392

Figure 1

Figure 2

Figure 3

Figure 4

Figure 5

Figure 6

Figure 7

Figure 8

Figures 9, 10

Figure 11

Figures 12, 13

Figure 14

Figure 15

Figure 16

Figure 17
Hedbergella delrioensis (Carsey); 390-3-3, 80-82 $\mathrm{cm}$; Ticinella primula Zone. $\times 250$.

Hedbergella delrioensis (Carsey); 390-3-3, 80-82 $\mathrm{cm}$; Ticinella primula Zone. $\times 250$.

Leupoldina pustulans (Bolli); 392A-3, CC; (?Schackoina cabri-) Globigerinelloides algerianus Zone. $\times 120$.

Globigerinelloides aff. saundersi (Bolli); 392A-3, CC; (?Schackoina cabri-) Globigerinelloides algerianus Zone. $\times 120$.

Hedbergella trocoidea (Gandolfi); 390-5-1, 87-89 $\mathrm{cm}$; Globigerinelloides algerianus Zone. $\times 75$.

Hedbergella trocoidea (Gandolfi); 390-5-1, 87-89 $\mathrm{cm}$; Globigerinelloides algerianus Zone. $\times 75$.

Hedbergella aff. trocoidea (Gandolfi); 390-3-3, 80$82 \mathrm{~cm}$; Ticinella primula Zone. $\times 150$.

Hedbergella aff. trocoidea (Gandolfi); 390-3-3, 80$82 \mathrm{~cm}$; Ticinella primula Zone. $\times 150$.

Globigerinelloides algerianus Cushman and Ten Dam; 390-5-1, 87-89 cm; G. algerianus Zone. $\times 80$.

Globigerinelloides algerianus Cushman and Ten Dam; 390-5-1, 87-89 cm; G. algerianus Zone. $\times 80$.

Globigerinelloides algerianus Cushman and Ten Dam; 390-5-1, 87-89 cm; G. algerianus Zone. $\times 80$.

Globigerinelloides ferreolensis (Moullade); 390-5-1, $87-89 \mathrm{~cm} ;$ G. algerianus Zone. $\times 155$.

Globigerinelloides ferreolensis (Moullade); 390-5-1, $87-89 \mathrm{~cm} ;$ G. algerianus Zone. $\times 155$.

Globigerinelloides ferreolensis (Moullade); 390-5-1, $87-89 \mathrm{~cm} ; G$. algerianus Zone. $\times 155$.

Globigerinelloides ferreolensis (Moullade); 390-5-1, $87-89 \mathrm{~cm} ;$ G. algerianus Zone. $\times 155$. 


\section{PLATE 10}

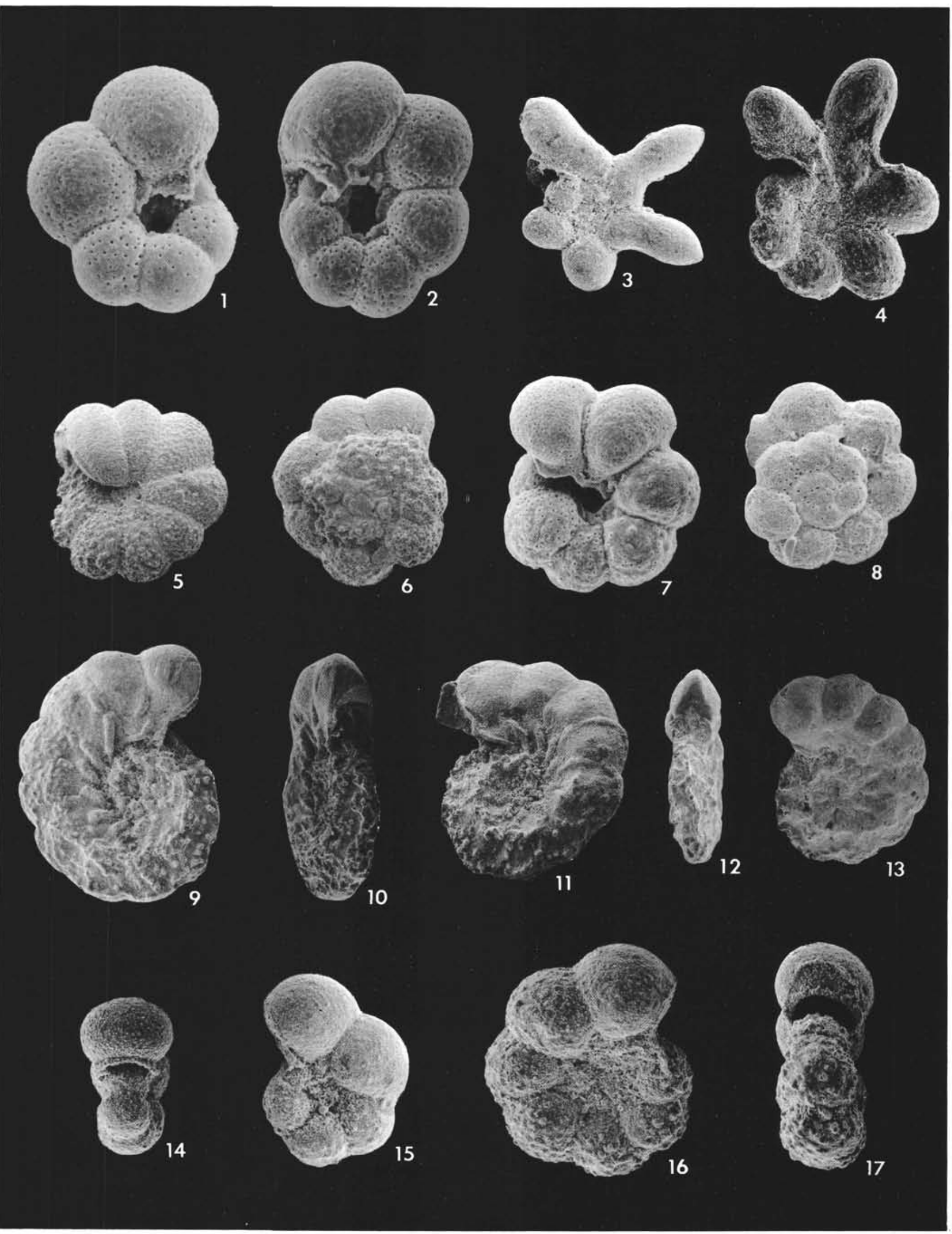




\section{PLATE 11}

Sites 390,392

Figure 1

Figure 2

Figure 3

Figure 4

Figures 5, 6

Figures 7, 8

Figures 9,10

Figure 11

Figure 12

Figure 13

Ticinella breggiensis (Gandolfi); 392A-2-1, 84-86 $\mathrm{cm}$; Ticinella breggiensis Zone. $\times 125$.

Specimen transitional between Ticinella primula Luterbacher and Ticinella breggiensis (Gandolfi); 392A-2-1, 84-86 cm; Ticinella breggiensis Zone. $\times 125$.

Ticinella primula Luterbacher; 390-3-3, 80-82 cm; Ticinella primula Zone. $\times 200$.

Ticinella primula Luterbacher; $390-3-3,80-82 \mathrm{~cm}$; Ticinella primula Zone. $\times 150$.

Ticinella primula Luterbacher; 390-3-3, 80-82 cm; Ticinella primula Zone. $\times 150$.

Ticinella primula Luterbacher; $390-3-3,80-82 \mathrm{~cm}$; Ticinella primula Zone. $\times 135$.

Ticinella primula Luterbacher; 390-3-3, 80-82 cm; Ticinella primula Zone. $\times 135$.

Hedbergella amabilis Loeblich and Tappan; 392A2-1, 84-86; Ticinella breggiensis Zone. $\times 135$.

Hedbergella amabilis Loeblich and Tappan; 392A2-1, 84-86 cm; Ticinella breggiensis Zone. $\times 135$.

Hedbergella amabilis Loeblich and Tappan; 392A2-1, 84-86 cm; Ticinella breggiensis Zone. $\times 135$.

Figures 14, 15 Hedbergella planispira (Tappan); 390-3-3, 80-82 $\mathrm{cm}$; Ticinella primula Zone. $\times 325$.

Figure 16 Hedbergella planispira (Tappan); 392A-2-2, 146$148 \mathrm{~cm}$; Ticinella breggiensis Zone. $\times 230$. 


\section{PLATE 11}
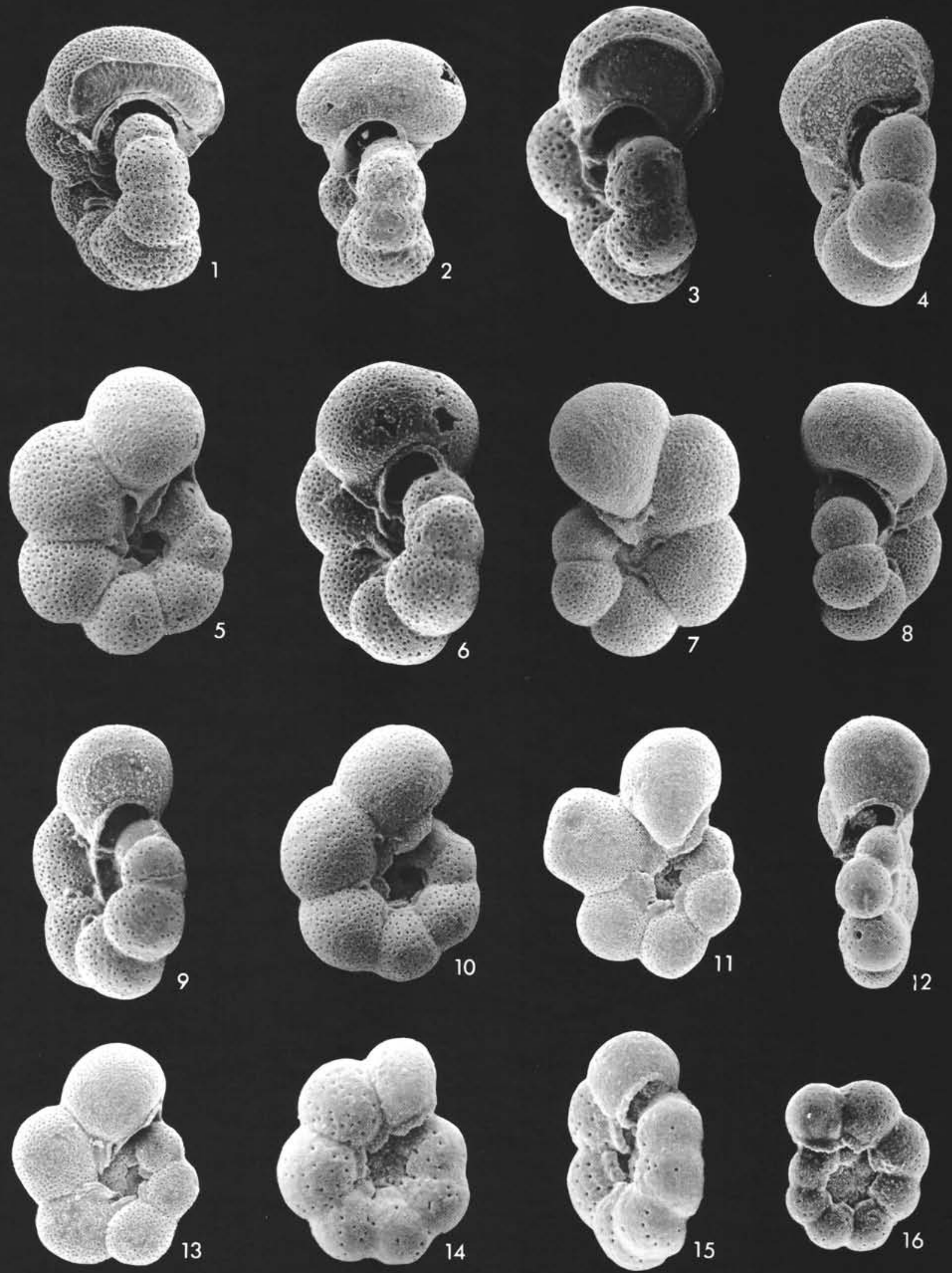